\title{
AFFECT, EMPOWERMENT AND THE COMPLEXITIES OF BELONGING: CULTIVATING A HUMANISTIC ATMOSPHERE IN THE ESL CLASSROOM
}

\author{
by \\ Momoye Sugiman \\ Bachelor of Arts (Honours), York University, Toronto, 1981 \\ A Major Research Paper \\ presented to Ryerson University \\ in partial fulfillment of the \\ requirements for the degree of \\ Master of Arts \\ in the Program of \\ Immigration and Settlement Studies
}

Toronto, Ontario, Canada, 2015

(C) Momoye Sugiman 2015 


\section{AUTHOR'S DECLARATION}

I hereby declare that I am the sole author of this Major Research Paper.

This is the true copy of the MRP, including any required final revisions, as accepted by my examiners.

I authorize Ryerson University to lend this MRP to other institutions or individuals for the purpose of scholarly research.

I further authorize Ryerson University to reproduce this MRP by photocopying or by other means, in total or in part, at the request of other institutions or individuals for the purpose of scholarly research.

I understand that my MRP may be made electronically available to the public.

Momoye Sugiman 


\title{
AFFECT, EMPOWERMENT AND THE COMPLEXITIES OF BELONGING: CULTIVATING A HUMANISTIC ATMOSPHERE IN THE ESL CLASSROOM
}

(C) Momoye Sugiman 2015

Master of Arts, 2015

Immigration and Settlement Studies

Ryerson University

\begin{abstract}
In this paper, I focus on the affective atmosphere of the Adult English as a Second Language (ESL) classroom. I argue that a humanistic learning approach can be a form of strategic resistance against the bureaucratization and standardization of publicly funded ESL programs for adult newcomers in Canada. Given the growing, top-down trend in our economically driven and technologically dependent society, there is a need to humanize the Canadian ESL classroom as a space for empathy and critical thinking. Through a literature review and semi-structured, in-depth interviews with former ESL learners and former ESL teachers, this paper reveals the psychological and political complexities of second language learning and cultural identity, as well as the pivotal role that an ESL teacher can play during the first few years of settlement. In this context, I also critique the racialized linguistic hierarchy embedded in Canada's multiculturalism policy and exclusionary immigration and language policies.
\end{abstract}

Keywords: critical pedagogy, humanistic psychology, multiculturalism, adult ESL, settlement 


\section{ACKNOWLEDGEMENTS}

I would like to express my gratitude to Professor Amina Jamal for her valuable guidance, insightful suggestions and unwavering encouragement as my supervisor. From the beginning, when I was still dithering over wide-ranging topics for my MRP, she advised me to focus on a familiar issue close to my heart. I am glad that I adhered to her advice.

Furthermore, the wisdom and kindness of Professor Carmen Schifellite should be recognized. I thank him for coming forward to be my second reader and providing precise, constructive suggestions. Since I am a relative novice in the field of social sciences, I found his Research Methods course extremely helpful during every step of my research.

It should also be acknowledged that this paper would not have been possible without the cooperation of the ten participants who consented to be interviewed. I sincerely appreciate them not only for sharing their time, thoughts and feelings, but also for the trust that they placed in me.

In addition, I will always be grateful to my beloved family and friends for their patience, understanding and support throughout my arduous and surreal return to academia.

Finally, I would like to thank my hundreds of former students. I dedicate this paper to all of the individual women and men whom I have had the privilege of learning from and teaching over the years. My precious conversations with them have enriched my life in many ways and influenced my view of the world. 


\section{TABLE OF CONTENTS}

Author's Declaration.......................................................

Abstract............................................................ii

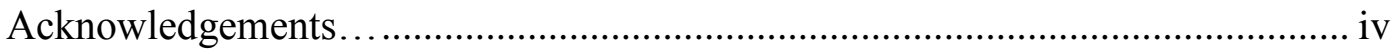

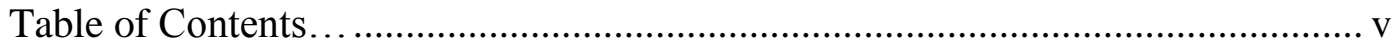

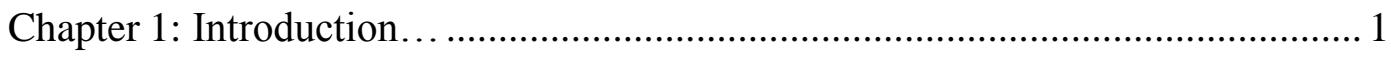

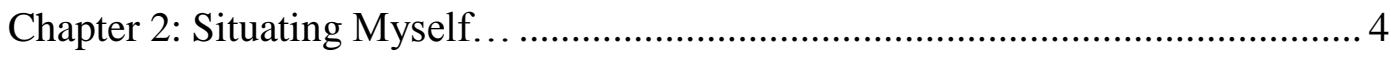

Chapter 3: Research Methods and Participants....................................................6

Chapter 4: Setting the Background and Reviewing the Literature

4.1 Unpacking Canada's Language and Immigration Policies................ 9

4.2 Cracking the Façade of the Multicultural Mosaic...........................15

4.3 A Multilingualism Ideology ....................................................... 17

Chapter 5: Conceptual Influences:

5.1 Humanistic Psychology ...............................................................19

5.2 The Enduring Legacy of Paulo Freire ............................................ 21

Chapter 6: Salient Interview Findings:

6.1 Summary of the Interviews.................................24

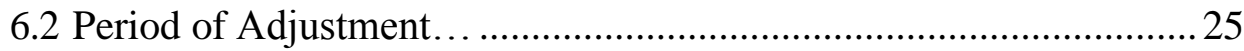

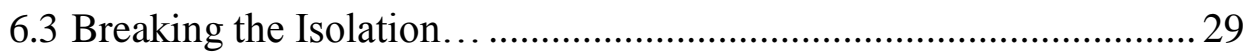

6.4 The Complexities Involved in Becoming "Canadian”................34

6.5 How Language Excludes... ......................................................... 39

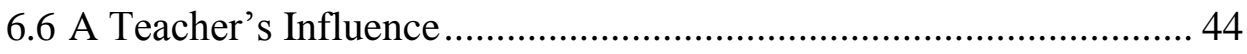

6.7 Preserving Teacher Autonomy .....................................................50

6.8 Transformative Learning Experiences ........................................ 52

Chapter 7: Pedagogical Implications..................................55

Chapter 8: Conclusion............................................61

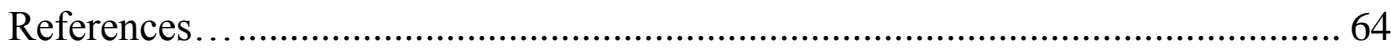




\section{INTRODUCTION}

Benchmarks, competencies, rubrics, eligibility criteria, checklists, national standards, formative/summative assessments, human capital, stakeholders, workplace-ready - these are among the buzzwords that have become all too familiar to seasoned English as a Second Language (ESL) teachers in publicly funded language programs for adult newcomers in Canada. In general, in the 1980s, ESL teachers in Canadian settlement programs enjoyed a certain degree of flexibility and creativity in terms of needs assessment and curriculum design, as most of them followed a basic communicative approach and tailored their lessons to the needs of their specific learners (Fleming, 1998). However, since the inception of national standards in ESL in the 1990s, teachers have had to deal with a growing web of bureaucracy and the chipping away of their autonomy (Fleming, 1998). The changes imposed over the past two decades include the introduction of the Canadian Language Benchmarks (CLBs), the Language Integration for Newcomers to Canada (LINC) program, and the Enhanced Language Training (ELT) initiative, all of which are part of an overall strategy tied to changes in our immigration policy (Fleming,1998, 2010). As I will discuss in greater detail in the literature review section of this paper, Fleming $(2009,2010,2015)$ asserts that the CLBs and related ESL citizenship documents are problematic because they reinforce a racialized linguistic hierarchy and conformity to a singular Canadian identity. Implicit in these documents is the notion that "[l]egitimate citizens are those who evoke whiteness and the ability to use standardized and high status versions of English" (Fleming, 2015, p. 82).

It is not surprising that the government's growing involvement in ESL instruction has coincided with its increasingly exclusionary immigration and citizenship policies, as evidenced by the Strengthening Canadian Citizenship Act (CIC, 2015a). The tightening of our borders has been systematic since the tragedy of September 11, 2001 (Kaushal \& Dauverne, 2011). Under these 
conditions, what are the implications for teachers and learners, especially racialized ones, in federally funded ESL programs for adult newcomers? According to Henry Giroux, we should be extremely wary of the state's interference in how and what is being taught, as he notes that we are living in "very dark times" of neoliberalism when democracy and civil liberties are under “assault" (Giroux, 2006, p. 31). In light of the current obsession with computer technology and workplace preparation in our education system, along with the federal government's increasing surveillance and control over ESL programs for newcomers, it can be argued that any grassroots sense of community and opportunities for meaningful self-expression and dialogue in our ESL programs are at risk. In this context, I explore the lingering potential of the ESL classroom as a transformative affective space. My central research question is as follows: In view of the growing trend towards commodification and standardization, how can the publicly funded ESL classroom become an empowering affective space that can help mitigate feelings of isolation and counter the dehumanizing impact of the government's assimilative, neoliberal agenda? And what is the role of the ESL teacher in helping to create such an empowering space?

Through the multi-faceted lenses of critical pedagogy and humanistic psychology, and supported by the voices of former ESL learners and teachers, I hope to demonstrate that an ESL classroom committed to humanistic principles can become a site for strategic resistance, a site for disrupting the status quo that keeps certain members of our society marginalized. Despite the constraining structural changes imposed on them, ESL teachers can have some degree of influence. They can either support assimilative government policies, obediently police their students and conform to the standardized government-designed curriculum guidelines — or they can exercise their professional autonomy by creating an empathetic learning environment that promotes critical thinking, creativity, human agency and solidarity. 
In Chapter 2, I declare my positionality and the impetus behind my research interests. This statement is followed in Chapter 3 by an outline of my research methods and a brief description of the participants in my study. Through my literature review in the fourth chapter, I aim to establish the theoretical framework for my paper. Citing several compelling works related to critical multiculturalism and critical pedagogy, I provide justification for contesting the insidious, exclusionary trends in Canada's immigration and language policies. Then, in Chapter 5, the fundamental principles of humanistic pedagogy, as articulated by Carl Rogers and Paulo Freire, are introduced as a form of resistance against the government's assimilative direction. In the sixth chapter, I present my primary qualitative research — specifically, the findings of ten interviewsto substantiate my contention that a humanistic approach in the Canadian ESL classroom can have a transformative, empowering impact on both teachers and learners. My paper ends with a section on various pedagogical implications followed by concluding remarks. 


\section{CHAPTER 2: SITUATING MYSELF}

As the sole researcher, I cannot pretend to be neutral and detached. I am an unabashed "insider" who comes to this research after three decades of teaching ESL to adult newcomers. I am familiar with the full gamut of ESL levels from literacy to academic preparation. Throughout my career, I have endeavoured to create a non-threatening, egalitarian atmosphere, an atmosphere conducive to the development of empathy and trust. In the intimacy of this atmosphere, many learners have opened their hearts to me about their deepest regrets and insecurities as well as their secret dreams. Over the years, in keeping with my humanistic philosophy, I have tried to convey to my students that the process of absorbing English and adjusting to Canadian society does not have to involve a rejection of any part of themselves in order to "fit in" and be accepted. I have also shared with newcomers my firm belief that every accent of English is valid and valuableand that becoming "Canadian" does not require knowledge of hockey rules or the British royal family. Moreover, becoming "Canadian" does not necessitate closing the door to one's homeland in order to prove one's loyalty to Canada.

Since my childhood, I have been drawn to the issues of learner self-esteem, cultural identity and racism, primarily because of my ability to reflect on my own cultural identity which continues to be shaped by my position as a member of a racialized minority group. As a sansei (i.e., third generation Canadian of Japanese ancestry), I grew up in a predominantly white, Anglo and Eastern European neighbourhood at a time when Toronto was far less multicultural than it is today. Consequently, I experienced the reality of a socially constructed, racialized subjectivity. Consciously or unconsciously, as a child, I internalized the message that my race would always mark me as somehow less "Canadian" in the eyes of others. As Kobayashi and Peake (2000) elegantly express it, "Whiteness is...a place from which to look at ourselves and the surrounding society, a position of normalcy, and perhaps moral superiority, from which to construct a 
landscape of what is the same, what is different" (p. 394). The conflation of "whiteness" with "Canadian" seems to be ingrained in the psyche of some newcomers. To illustrate, throughout my teaching career, invariably, at least once per term, a new student, standing in the doorway of my classroom and holding a registration form, would turn around and walk out upon realizing that I was the teacher. In some cases, I would be informed later that the potential learner had gone to the school office to request "a Canadian teacher", which can be interpreted as "a white teacher". In the course of my research for my MRP, I discovered that such a reaction is not unusual. Apparently, various other racialized ESL/EFL teachers have encountered "the prevalent belief" among learners that "the only legitimate speakers of English" and "the ideal teachers of English" are white (Kubota, 1999, p.101).

Finally, as an ESL teacher, I have also participated in a gradual shift towards a streamlined, centralized ESL system geared to the labour market and prescribed by the federal government. Over the past few decades, with each new directive from the administration, I have found my professional obligations at variance with my pedagogical philosophy, teaching style and personal ethics. As a result, I have been suffering from the erosion of my autonomy and the stultification of my creativity amid mounting bureaucratic duties, as well as rigid curriculum guidelines and evaluation criteria with which I am expected to comply. Feeling frustrated by my powerlessness, I have felt compelled to question the far-reaching and multidimensional implications of the federal government's immigration policies and involvement in ESL programs for newcomers. It is my sense of frustration as a teacher that has prompted me to research the nexus between critical pedagogy and humanistic psychology. 


\section{CHAPTER 3: RESEARCH METHODS AND PARTICIPANTS}

My main objective was to glean candid, in-depth reflections on the ESL experiences of newcomers, as well as their views on cultural identity, multiculturalism and language policies. Keeping that objective in mind, I interviewed eight former ESL learners who now hold either permanent residency status or Canadian citizenship. To add a further dimension to the discussion, I also recorded the reflections of two experienced but retired ESL teachers. The recruitment of participants was conducted through a snowballing method, beginning with an initial email sent out to numerous friends, acquaintances and former students whom I suspected would have contacts in a wide spectrum of large immigrant communities. Hence, the recruitment was purposive and designed "to select unique cases that are especially informative" (Neuman, 2011, p. 268). In this study, the purpose was to gather narrative data through the lenses of individuals who would be willing to reflect openly on their ESL experiences. I was seeking retired teachers who had gained a positive reputation among their learners and who had witnessed firsthand the impacts of government cutbacks and ESL restructuring. As for the selection of former ESL learners, I was aiming for diversity in terms of age, country of origin, and length of time in Canada. In addition to exploring the cross-cultural aspect, I wanted to determine if there were any gender differences. Thus, I sought a balance of men and women. Additionally, I wanted to ensure that at least half of the former students would be individuals who were designated as convention refugees or refugee claimants during the initial period of their ESL studies. Furthermore, I had hoped to find former learners who had only a limited number of social contacts when they arrived, but who developed close friendships with ESL classmates.

To protect confidentiality, each of the ten participants was asked to select a pseudonym. Pseudonyms were also created to conceal the identity of particular Toronto area schools, former classmates and teachers. The two retired teachers, both of whom most recently taught 
intermediate levels, are noted as "Angela" and "Millie". The eight former ESL learners consist of four women: "Julie”, who claimed refugee status upon her arrival from Turkey; "Mei Yi”, a Chinese Panamanian who entered initially as an international student and soon became a permanent resident; "Nadine" who arrived as a permanent resident from Brazil, and "Mona", a government-assisted refugee (i.e., a convention refugee selected by the government for immediate permanent residency) from Iran. The male participants are "Mtobe" who came as a refugee claimant from the Democratic Republic of Congo; "Karim", a former refugee claimant from Palestine; "Ali”, who started off as a government-assisted refugee from Afghanistan, and "Josef", a Hungarian who arrived as a permanent resident. To further minimize the risk of compromising confidentiality, I have not attached full demographic details (marital status, age, former occupation, education level, date of arrival, and so on) to specific individuals. Suffice it to say that the initial education level ranged from one year of university or college to a master's degree. The participants' ages at the time of arrival span from approximately 20 to 40 years old. Their occupational backgrounds include the fields of graphic art, agricultural engineering, law, international development, teaching, nursing, audio-visual technology and business. Finally, all the participants were attending government-funded ESL classes in Toronto for at least six months at some point between 2000 and 2014. Please note that I refer to the eight former ESL students as "learners" and the two former ESL instructors as "teachers" throughout my paper.

Recruitment, interviewing and transcribing took place within a seven-week period. Initially, considering my vast personal and professional networks in numerous immigrant communities, I had not anticipated any difficulty in finding participants who would correspond to my original criteria. However, due to time constraints and unforeseen logistical circumstances, I altered my criteria slightly midway through the recruitment process in order to secure willing 
participants within my time frame. For instance, I was obliged to place immediate availability as a priority over degree of social isolation upon arrival and diversity in terms of region of origin.

It should also be noted that I had planned to pose only a handful of broad, open-ended questions as prompts and allow the narratives to flow freely. While the four female learners were extremely forthcoming, offering lengthy responses in interviews lasting over an hour each, two out of the four male learners provided comparatively succinct and somewhat stilted responses. After unsuccessful attempts to elicit greater detail from these men, I reverted to a long list of prepared questions. Thus, although the interviews with the men are informative and meaningful, the findings reported in this paper are dominated by the voices of the women.

It is acknowledged that the participants are not representative of all ESL learners or all ESL teachers. However, their remarks reflect the rich multiplicity of human experience and the evolving, multi-layered nature of cultural identity. Since each life is shaped by a unique set of intersecting circumstances, social contacts and life experiences, the opinions and narratives of individual learners and teachers contribute original strands to the existing body of research on language, identity and power. 


\section{CHAPTER 4: SETTING THE BACKGROUND}

\section{AND REVIEWING THE LITERATURE}

\section{1: Unpacking Canada's Language and Immigration Policies}

In Canada, we profess our loyalty to a person who represents all Canadians and not to a document such as a constitution, a banner such as a flag, or a geopolitical entity such as a country. In our constitutional monarchy, these elements are encompassed by the Sovereign (Queen or King). It is a remarkably simple yet powerful principle: Canada is personified by the Sovereign just as the Sovereign is personified by Canada. (Citizenship and Immigration Canada [CIC], 2009, p. 2)

The above passage, titled "Understanding the Oath", appears on the inside cover of the most recent citizenship preparation guide, Discover Canada: The Rights and Responsibilities of Citizenship. With this concise explanation of Canada's oath of citizenship, the oath pledging allegiance to the British monarch, the Harper government proclaims its vision of a nation with a dominant British character rather than a colourful mosaic comprised of a myriad of equal cultures. It is also significant that Discover Canada ignores or minimizes the racist stains in our country's history, such as the systemic cultural genocide and sexual and physical abuse of Aboriginal children, yet the new guide prominently includes several pages glorifying Canada's military feats and British heritage (CIC, 2009). The immigration gatekeepers-that is, the politicians who decide who is allowed the coveted privilege of entering this country—claim pride in our rich ethnic and linguistic diversity. At the same time, however, the Canadian government has been constructing policies, programs, ESL guidelines and citizenship preparation materials that could lead one to question the depth of our celebrated multiculturalism. 
Citing Citizenship and Immigration Canada documents, Douglas Fleming (1998) points out that "a major shift in immigration policy" occurred in the early 1990s, as "increased immigration was required for economic growth into the new century and...the skills of immigrants were important resources to be utilized" (p. 22). As Fleming reveals, according to the government, "[t]hese skills could only be effectively put to use for the nation through the development of more efficient and effective language training" (p. 22). First, in 1992, there was the introduction of the Language Instruction for Newcomers to Canada (LINC) program which focuses on the functional language integration needs of new immigrants (CIC, 2013). In 1998, the Centre for Canadian Language Benchmarks was established as "the national standard setting body for the Canadian Language Benchmarks (CLB)" (CIC, 2012). Ostensibly, these programs serve a legitimate purpose by setting a standard across the nation. Nevertheless, as Fleming (2010) incisively points out, the precisely worded competencies and sample tasks for the twelve benchmark levels are contestable. A discourse analysis of the exhaustive CLB curriculum guidelines and associated materials brings into question the "nature and purpose of adult English language programming in Canada", since these documents impose a rigid uniformity and condescendingly "position ESL learners as powerless and passive" and as "recipients of programming that is designed to normalize them into a dominant culture" (Fleming, 2010, p. 610). In Canada, that dominant culture is the white, Anglo culture of the colonizer.

The government's introduction of fixed language benchmarks, matched with a set of specific, culture-bound curriculum guidelines, was eventually followed by stringent immigration and citizenship policies, including ones pertaining to language. On June 11, 2015, the "final group of reforms" in the Strengthening Canadian Citizenship Act (SCCA, Bill C-24) was implemented, and included among the sweeping changes in the SCCA is a new language requirement for young adolescents and adults on the brink of retirement who want to apply for either Canadian 
citizenship or permanent residency (CIC, 2015a). Under the new law, anyone from 14 to 64 years old must provide evidence of proficiency in either English or French. Previously, the age range for this language requirement was 18 to 54 (CIC, 2015a). Applicants can choose to prove their English proficiency by certified completion of at least CLB 4 in a government-funded program or by results of a third-party test, specifically, the "CELPIP-G" (Canadian English Language Proficiency Index Program General Test), the "CELPIP-General LS" (Listening and Speaking) or the "IELTS General" of the International English Language Test System (CIC, 2015b).

Canada's raising of the language bar is also evident in the Comprehensive Ranking System for prospective permanent residents under the Express Entry System; a CLB assessment score of 4 or 5 would give an applicant a maximum of only 6 points, and a CLB score of 10 or higher would garner 34 points for unmarried applicants and 32 points for married applicants or those with a common-law partner (CIC, 2015c). Even a cursory examination of the Express Entry points system indicates that the higher the level of English, the greater the likelihood of being selected. However, by placing such a high priority on English language proficiency as a prerequisite for permanent residency, Canada could be losing many hard-working, earnest individuals who are being screened out automatically because their English does not measure up to some unrealistic standard judged within the artificial confines of a time-limited, formal test. Moreover, this new language policy gives an unfair advantage to candidates from the United Kingdom, Australia, the United States, South Africa, and other countries where English is the lingua franca. The most disturbing aspect of the Harper government's immigration policy is the fact that the Minister of Immigration has the executive power to cherry pick the candidates who will be "invited" to immigrate to Canada (CIC, 2015d). With such unbridled discretionary power, there is no mechanism for accountability. One individual has the power to select or discard applications based on his own whims and prejudices. 
The whole issue of language testing is contentious. According to Shohamy (2007), language tests are powerful, "covert" tools of cultural control and "gate-keeping", as they are often used for "implementing a variety of public policies resulting in unethical immigration policies", such as the "repatriation" of long-time residents, in addition to "denying residence, entrance to educational institutions and the workplace" (p. 126). Furthermore, a language test as a condition of citizenship is problematic, since there is no verified correlation between proficiency in an official language and good citizenship, particularly in a multilingual, globalized world with various "language hybrids and fusions" (Shohamy, 2007, p.127). Another objectionable aspect of such tests is the fact that they are cost-prohibitive. An applicant may have to take the test repeatedly until the desired score is achieved. At present, the cost of the CELPIP-General can range from $\$ 265$ to $\$ 365$, depending on the province (CELPIP, 2015); the current average fee to take the IELTS-General in Canada is $\$ 300$ (IELTS Canada, 2015). It can also be argued that this new policy favours applicants of a higher socioeconomic class who can afford extensive test preparation classes and daily exposure to computer technology.

The new language requirements are blatantly exclusionary, deepening both class and generational divides. While the IELTS is still paper-based, the CELPIP is computer-based, but both tests involve rigidly time-limited tasks (CELPIP, 2015; IELTS, 2015). These conditions might be inordinately anxiety-provoking for a person with undiagnosed learning disabilities or for a 64-year-old applicant who has never touched a computer keyboard. Finally, according to sample practice material available on the test organizations' websites (CELPIP, 2015; IELTS Canada, 2015), these tests contain colloquial phrases and content specific to the dominant white cultures of Canada, the United States, Britain and Australia. Also, the accents of the speakers in the listening sections are definitely not identifiable as accents of Chinese, Jamaican or Bengali-tinged English - unless the speakers are in the role of "international student", whereas Standard 
American, Australian and various British accents can be heard in the listening section of the IELTS in the speech of authority figures, such as professors and university administrators (IELTS Canada, 2015). Therefore, these proficiency tests convey the message that some accents of English are intrinsically superior to others.

Canada's introduction of standardized language tests as part of the citizenship process institutionalizes a linguistic hierarchy, which reflects a residue of colonialism and the "Othering" of racialized immigrants. As Shohamy (2007) asserts, such tests reinforce the message that diversity will be tolerated only up to a certain point. Ultimately, they override notions of linguistic and cultural plurality and perpetuate the "elimination of the unique knowledge of minority groups" (Shohamy, 2007, p. 123). Moreover, formal language proficiency tests could place an undue psychological burden on those permanent residents who started off in this country as refugee claimants and who were fleeing persecution because of their ethnic minority status and distinctive languages. After the ordeal of having to prove their refugee claims, these individuals are forced to prove that they are worthy of Canadian citizenship by demonstrating their knowledge of English or French, the languages of the two founding colonial powers. Clearly, this policy disenfranchises a huge segment of the population who may never be able to measure up for reasons of age, educational level and "foreign" accents labelled as inferior. Gender must also be considered, as some older women who arrive under the family reunification sponsorship category may not have had the opportunity to complete high school in their homelands.

By demanding an unrealistically high standard of "correct" English, the government is reinforcing a hegemonic, homogenous, British-American national character that undermines not only the legitimacy of other languages and cultures, but also other varieties of English (Phillipson, 1998, Shohamy, 2007; Tomic, 2013). According to Bourdieu, those "speakers lacking the legitimate competence are de facto excluded from the social domains in which this competence is 
required, or are condemned to silence" (Bourdieu, 1991, p. 55). Hence, a compulsory test to evaluate linguistic competence intensifies the social exclusion of marginalized immigrants and refugees. It blatantly promotes an assimilative agenda contrary to Canada's professed principles of equality and democracy.

The potential of English as a tool of cultural domination is indicated in the deprecation and racialization of certain accents of English. For example, Gillian Creese (2011), who studied the accent devaluation of Sub-Saharan African immigrants in Vancouver, found that the negative prejudice faced by racialized immigrants is a direct consequence of their "foreign accents" of English. In everyday interactions in the workplace and at school, the respondents reported that despite their high levels of education in the English medium, their accents were perceived as inferior by the dominant white population. "[M]arked as African, Black, immigrant" through their accents, both men and women reported a sense of not belonging because "their linguistic authority is undermined" (Creese, 2011, p. 305). Substantiating this finding is the work of Tomic (2013). After 40 years as an academic in Canada, she claims that she is still treated condescendingly because of her Spanish-accented English. From her perspective, this denigration of non-native speakers of English helps maintain the unequal balance of power, as these speakers are viewed as the Other, and they live in a constant state of striving to "assimilate into an unreachable norm" (Tomic, 2013, p. 5). For Tomic, this situation "must be traced in colonialism." (p. 17). The interwoven issues pertaining to English language acquisition, Canadian citizenship and cultural identity construction have been explored in depth by Tara Gibb $(2008,2010)$. She asserts that the Canadian Language Benchmarks and other language policy documents are embedded with questionable discourses of Canadian culture — discourses mired in our colonial past. Gibb (2008) critiques the commodification of the ESL learner and the English language, as she points out how the CLB documents objectify learners in terms of their potential contributions to the 
Canadian economy. According to Gibb, "[m]erely listing sets of prescribed skills and standards that workers and immigrants are expected to demonstrate masks whose knowledge is to be adopted and performed" (Gibb, 2008, p. 332). She also argues that second language learning does not take place in isolation, for it is an intricate "social process occurring within relations of power" in our education and employment institutions (p. 332).

\section{2: Cracking the Façade of the Multicultural Mosaic}

The current government's latest changes to our immigration and citizenship policies, with their emphasis on the English proficiency and the employability of newcomers, bring into question the interpretation of multiculturalism in the age of globalization. The research of Douglas Fleming (2010) underscores the flimsiness of attaching English language fluency to citizenship in today's transnational world, as many of the respondents in his study, immigrants from India, acknowledge the value of English as a tool of communication, but they feel there is nothing “incompatible with conducting the greater part of their daily lives in Punjabi and being a good Canadian citizen" (Fleming, 2010, p. 609). Although the participants in Fleming's study speak about democracy, multiculturalism and their rights as citizens to participate in the political process, they maintain that the government's ESL curriculum materials do not give them much of a chance to learn specifics about their rights as citizens or as workers and how they can empower themselves (Fleming, 2010).

Yan Guo (2013) offers a similar analysis of Canada's ESL policies and programs through the lens of multiculturalism, with a particular focus on the historical fact that many immigrants to Canada are racialized and come from the Middle East, Asia, Africa and Central and South America. It is no coincidence that this demographic shift has been accompanied by more heavyhanded control of our publicly funded ESL programs, not only in terms of administration but also in the area of curriculum design. Guo challenges Canada's multiculturalism discourse and 
citizenship preparation materials. She deplores the growing trend towards cultural assimilation and advocates an ESL system reflecting "a 'pluralistic citizenship' that recognizes...multiple attachments to specific languages, cultures and values..." and considers "plural ways of belonging..." (Guo, 2013, p. 38). To substantiate her critique, Guo (2013) offers the example of a workshop facilitator who was advising new immigrants to "think like a Canadian" in the workplace. An immigrant himself, this facilitator had "internalized an assimilationist mentality", as he was implying that anyone with an "ethnic" background, such as "Chinese or Iranian", was somehow not genuinely "Canadian" (Guo, 2013, p. 34). It could also be argued that this workshop facilitator was revealing a classic colonial mentality.

Multiple ways of belonging and the interconnections of language and identity in a multicultural society have been further explored by Bonnie Norton who has convincingly added the dimension of affect to the discussion. She suggests that certain second language (L2) acquisition theories, such as Krashen's affective filter model, are simplistic and inadequate, since they fail to address the social inequities that may influence a learner's affect (Norton, 2013). As she states, many theorists assume that we can neatly categorize learners as "motivated or unmotivated, introverted or extroverted, inhibited or uninhibited", without taking into account that such affective factors evolve "over space and time" and are "frequently socially constructed in inequitable relations of power" (Norton, 2013, p. 45). Additionally, Norton focuses on how the psychological construct of motivation can be thwarted by the social construct of investment (Norton, 2013). Even highly motivated learners could choose not to participate if the practices of a particular ESL classroom or community are incompatible with their individual language needs or perceptions of effective language teaching (Norton, 2013; Pavlenko \& Norton, 2007). Norton extends the concept of "imagined communities", a term originated by Benedict Anderson (1991). In the context of L2 learning, this phrase denotes the learner's perception of the target community 
and the associated imagined identity to which the learner aspires, despite non-engagement in that community (Norton, 2013; Pavlenko \& Norton, 2007). She also questions the "ownership" of the English language in today's globalized world, suggesting that "English belongs to the people who speak it, whether native or nonnative, whether ESL or EFL, whether standard or nonstandard..." (Norton, 1997, p. 427).

Lilia Bartolomé (2010) and Ryuko Kubota (2010) add thought-provoking threads to the discussion of language, identity and multiculturalism. Bartolomé critiques the non-threatening, liberal brand of multiculturalism that is displayed for photo opportunities at festivals, as it disguises deeply entrenched power relations that marginalize newcomers as "ethnics". She believes that teachers have a moral obligation to become sensitized to the underlying ideologies in ESL education (Bartolomé, 2010). Thus, she calls for the inclusion of a counter-hegemonic ideology in all aspects of teacher preparation courses and the creation of "spaces for students' voices to emerge" (p.49). In this light, an ESL teacher's adherence to language policies and programs designed to maintain the status quo can be viewed as complicity. Like Bartolomé, Kubota (2010) offers compelling support for a critical analysis of ESL policies and curriculum material. Citing her 2004 article, she asserts that Canada's multiculturalism discourse perpetuates "colour or difference-blindness, and exoticizes and essentializes the culture of the Other, while obscuring issues of power and privilege" (Kubota, 2010, p. 99). Finally, she challenges the "institutional status" of English, pointing out that ESL teachers of colour often encounter discrimination from their students who cannot conceive of a non-white teacher being sufficiently competent as an English teacher compared to a white teacher (p. 100).

\section{3: The Ideology of Multilingualism}

The idea of plural ways of belonging suggested by the previously noted scholars leads directly to the transformative power of multilingual education. Given the intertwining social, 
political and affective threads of language and identity, a genuinely inclusive society in a globalized world would be one that recognizes multiple languages. The extensive work of Jim Cummins $(2000,2001,2007)$ gives tremendous credence to the ideology of multilingualism, that is, an ideology that elevates the status of other languages and challenges the Anglocentrism of our education system. Although Cummins conducted his research on immigrant children, his basic theories can be logically applied to the adult second language learner. Most significantly, he has demonstrated the profound impact of the first language on L2 learning. Cummins advocates the development of a supportive, co-operative learning environment in which learners can express their thoughts freely, negotiate healthy cultural identities — and feel comfortable using English alongside their first language (Cummins, 2000, 2001, 2007).

Raising the status of "non-official" languages is particularly relevant in Canada, a country that has heritage language rights enshrined in its Charter of Rights and Freedoms. It is also particularly relevant at a time when the federal government is setting the English language proficiency standard at an unreasonably high level for potential immigrants and citizens (CIC, 2015a; CIC, 2015c). The ideas of Jim Cummins are supported by the research of Tove SkutnabbKangas $(1994,1998)$ who believes that "linguicism", that is, the linguistic imperialism of English, is threatening to send many unique languages and dialects on the path to extinction. In this context, she proposes that language rights be included under human rights, as "linguodiversity is a necessary prerequisite for democracy and informed participation" (Skutnabb-Kangas, 1998, p. 20). Furthermore, she argues that being able to gain "[a]ccess to both one's own and other languages is a necessary...prerequisite for identity and analysis, for empowerment of the B-team and for counter hegemonies" (p. 20). 


\section{CHAPTER 5: CONCEPTUAL INFLUENCES}

\subsection{Humanistic Psychology}

At the theoretical heart of this research paper is humanistic psychology as it pertains to L2 education. I argue that a teacher who genuinely embraces this approach can at least diminish the dehumanizing impact of the government's increasing commodification of the ESL learner. Popular in the 1960s and 1970s, humanistic pedagogy is grounded in the belief that the learner's affective dimensions must be addressed if meaningful learning is to take place, since affective and cognitive processes are interrelated (Arnold \& Brown, 1999; Brown, 1980). Affect can be defined broadly as "aspects of emotion, feeling, mood or attitude which condition behaviour" (Arnold \& Brown, 1999, p. 1). Humanistic learning theory focuses on the whole person and considers inextricably interwoven facets of human psychology, including anxiety, inhibition, extroversionintroversion, motivation and empathy (de Andres, 2002; Arnold \& Brown, 1999; Rinvolucri, 1999, Stevick, 1999). The integral role of affect in language learning has also been recognized by various scholars of applied linguistics, including Stephen Krashen (1981) who developed the theoretical construct of the affective filter, that is, the theory that certain emotions, such as anxiety, can block second language input.

In addition to emphasizing the role of affect, humanistic learning underscores the dignity of human beings and their innate capacity to strive towards self-actualization after they have met other needs (physiological, safety, belonging, self-esteem) in a theoretical hierarchy of human needs (Maslow, 1958). Along with Maslow, Carl Rogers is considered a "pioneer" of humanistic psychology; he wrote and spoke extensively about the inherent self-worth, human potential and evolving nature of each learner (Rogers, 1995; Rogers et al., 2013). According to Rogers and his adherents, learning is facilitated when learners feel a bond of mutual respect and understanding among themselves as equals in a non-judgmental atmosphere (Rogers, 1995; Rogers et al., 2013). 
This person-centered philosophy places enormous value on building trust among members, including the teacher, who assumes the role of a facilitator, thus relinquishing authority and revealing his or her genuine, vulnerable self instead of acting as a superior who holds all the answers (Rogers, 1995). In such a non-threatening atmosphere, not only is the uniqueness of each member of the group appreciated, but also an attempt is made to be empathetic and to deeply understand the other person's frame of reference (Rogers, 1995). In other words, empathy is an "attitude of standing in the students' shoes, of viewing the world through their eyes" (Rogers, 1995, p. 273). According to Rogers, "empathy dissolves alienation", as the individual "finds himself or herself a connected part of the human race" (Rogers, 1995, p.151). In the context of the multicultural ESL classroom, I have witnessed that empathy helps to dissolve boundaries between ethnocultural groups, since learners see their classmates as fellow human beings rather than representatives of particular nations.

Central to humanistic philosophy is the notion of learner self-esteem. Rebecca Oxford defines self-esteem as "a self-judgment of worth or value, based on feelings of efficacy, a sense of interacting effectively with one's own environment” (Oxford, 1999, p. 62). Citing Price (1991), Oxford posits that learning a second language can pose a threat to self-esteem, since learners are denied their usual modes of communication, and when learners are experiencing high anxiety, they are better able to cope if they have high levels of self-esteem (Oxford, 1999). While most of the research on self-esteem in second language acquisition (SLA) has looked specifically at children, certain theoretical premises can be logically extended to adult immigrant ESL learners who are also in a state of flux as they re-evaluate their lives and adjust to their new environment.

Another contributor to the study of humanistic language learning is Gertrude Moskowitz (1978) whose practical exercises, specifically designed for the ESL classroom, aim for personal 
growth by stimulating the imagination. Like Rogers, Moskowitz values empathy and self-esteem, and she views the learning environment as a space "where it is safe to share" (Moskowitz, 1978, p. 27). Instead of treating the foreign language learner as an empty vessel, the humanistic language teacher acknowledges the interconnectedness of language and identity and legitimizes the learners' feelings and lived experience by weaving them into the content of the class curriculum (Moskowitz, 1978). Arguably, an unwavering insistence on self-esteem building through "low-risk" activities and the avoidance of any negativity could be seen as patronizing. Such a preoccupation with the creation of a positive, nurturing environment of intercultural harmony can be associated with the depoliticized, non-disruptive brand of liberal multiculturalism (May \& Sleeter, 2010). Even so, Moskowitz's practical exercises for inspiring the imagination and promoting meaningful interaction are worth investigating. Her evidence-based research indicates that open-ended, humanistic exercises can enhance motivation and serve the universal needs of "being listened to, accepted, understood, cared about..." (Moskowitz, 1999, p.179).

\subsection{The Enduring Legacy of Paulo Freire}

The humanistic philosophical foundation laid by the late Carl Rogers and his contemporaries has influenced various other scholars, including Maureen O'Hara $(1989,2003)$ who studied with Rogers and went on to write about the ways in which his basic principles for person-centered counselling groups could be "reframed, renamed and updated" to address social inequities and world conflicts — and thus to help create "a sustainable, civil global society" (O’Hara, 2003, p. 65). In fact, O’Hara (1989) informs the reader that Rogers, during his final years, found ideological alignment with the critical pedagogy presented by the late Brazilian educator Paulo Freire in his classic Pedagogy of the Oppressed (1970/2000). O'Hara recognizes that both of these thinkers addressed uneven power relations. However, she notes that while Rogers wrote primarily about the relationship between the individual and various groups such as 
the family and community, Freire was more concerned with "the disparity between dominant and dominated groups” in the world (O’Hara, 1989, p. 19). As O’Hara points out, Rogers developed his political thinking comparatively later in life, with the publication of On Personal Power in 1977, and most of his previous writing was based on interactions with his fairly middle class clientele, compared to Freire's grassroots work with marginalized farm workers in Brazil. Nonetheless, when we examine the works of these two inspirational men, certain shared tenets are undeniable. O'Hara (1989) remarks that both Rogers and Freire believed in the intrinsic power and dignity of the human being as an active, self-directed agent. She also states that both men expressed the urgent need to hear students' voices in a respectful atmosphere where the teacher's role is that of an empathetic listener rather than an authority figure with superior knowledge.

Obviously, though, Freire's direct contact with the working class made him much more politicized than Rogers. According to Freire (1970/2000), the teacher has a responsibility to connect education to social change, specifically the emancipation of the marginalized and exploited. O'Hara (1989) highlights the core Freirean notions of solidarity-building, dialoguing, the transformative power of the imagination and critical thinking - as well as his critique of the banking of knowledge, that is, the mechanical, passive memorization of knowledge that is fed to students by the teacher and "anaesthetizes and inhibits creative power" (Freire, 2000, p. 81). As a stark alternative to the stultifying banking concept, Freire offers the problem-solving method that encourages open dialoguing and recognizes that learners are capable of critical thinking or conscientization. "Problem-posing education bases itself on creativity and stimulates true reflection and action upon reality..." and recognizes that human beings are in a perpetual state of incompleteness or "becoming" (Freire, 2000, p. 84).

Ellsworth (1989) has criticized Freire for failing to adequately address the interlocking 
oppressions of racism and sexism. However, I believe that Freire's opposition to all forms of domination and oppression is implicit in his call for human liberation. As McLaren (1999) notes, Freire's ideas have laid a foundation for further explorations of transformative social justice, inspiring "a wide array of anti-sexist, anti-racist, and anti-homophobic classroom-based curricula and policy initiatives" (p. 51). In further defense of Paulo Freire, I point to the work of bell hooks (1994). An African-American feminist scholar of critical pedagogy, hooks speaks from the interwoven perspectives of anti-colonialism, anti-racism and feminism. She credits Freire as her major philosophical influence, for she was introduced to his work at a crucial point in her life when she was questioning the inequities in the world around her. As hooks states, "Paulo was one of the thinkers whose work gave me a language. He made me think deeply about the construction of an identity in resistance" (hooks, 1994, p. 46).

Freire has also influenced subsequent theorists, including Henry Giroux who has contributed hundreds of articles to an extensive body of literature under the umbrella of critical pedagogy. In his book Education and the Crisis of Public Values (2012), Giroux devotes the closing chapter to Freire, praising him for starting an "educational movement guided by both passion and principle to help students develop a consciousness of freedom..." (p. 116). Alarmed by the growing impact of technology, the mass media and the economic imperative in our education system, Giroux $(2006,2011,2012)$ writes persuasively about the pressing need to challenge the neoliberal trend by nurturing critical thinking, creativity, and the autonomy of both students and teachers. He deplores the increasing emphasis on "standardization, high-stakes testing, rigid accountability schemes, and privatization"-all features of a system designed to produce obedient, unquestioning workers and "lifelong consumers" (Giroux, 2006, p. 21). 


\section{CHAPTER 6: SALIENT INTERVIEW FINDINGS}

\section{1: Summary of the Interviews}

Given my focus on the affective dimensions of language learning and issues of identity, belonging and power, it is fitting to include the thoughts and feelings of individuals who have had direct experience in ESL classrooms. When I reviewed the transcripts of all ten interviews, the following themes emerged as the most prominent: initial adjustment issues, the reduction of isolation through friendships, the complexities of becoming "Canadian", linguistic discrimination, the significance of the teacher's personality, teacher autonomy, and transformative experiences.

Overall, regardless of their age, gender, level of English or length of time in Canada, the learners whom I interviewed hold a relatively positive attitude towards Canadian society and their ESL experiences. It is also interesting that all the women speak fondly about the enduring crosscultural friendships they formed with individuals they met in their early ESL classes, yet only two of the men mention such intimate and long-lasting "ESL friendships". These friendships constitute a cherished support network-which one learner labels as "a family of friends". Also, all of the learners describe at least one exceptional teacher who connected with them on a personal level, acted as an advisor and helped them build their self-confidence.

In general, the men were more hesitant about revealing feelings of insecurity or minute details about their ESL friendships. Considering the limitations of my research, I cannot make any formal speculations about this gender difference. Perhaps it can be attributed, in part, to sex role socialization. Perhaps it can be traced simply to individual degrees of introversion versus extroversion. Perhaps with a larger sample, this finding would be negligible. Conversely, it could be even more pronounced. Therefore, exploring the role of gender in cross-cultural friendships and self-disclosure could be an area for future research on newcomers. As for the two teachers who were interviewed, they both speak openly about the detrimental impact of government 
cutbacks, their deep appreciation for the lived experiences of their learners and the value of fostering a sense of community in the classroom. The interviews also reaffirm the importance of listening to individual voices and promoting a pedagogy that views the inherent self-worth of learners as more precious than their potential contributions to the nation's economy as unquestioning workers, investors and consumers.

\subsection{Period of Adjustment}

Despite the Internet's blurring of cultural boundaries over the past two decades, most of the learners, including the ones who immigrated fairly recently, report some degree of culture shock upon their arrival in Toronto. According to H. Douglas Brown (1980), the phenomenon known as "culture shock" can range "from mild irritability to deep psychological panic and crisis", and it is "a common experience for a person learning a second language in a second culture" (p. 131). Drawing upon the work of Peter Adler (1972), Brown goes on to note that culture shock does not necessarily have to be a state of crisis but a cross-cultural experience of personal growth (p. 134).

This wider view is apparent in the comments of all the learners in my study. With the exception of Josef from Hungary, who refers to himself as "very flexible", the other learners remember varying degrees of initial disorientation, depending on the conditions they had come from and the conditions they encountered upon their arrival here. Everything is relative, as illustrated by the experience of Mtobe of the Democratic Republic of Congo. Mtobe ranks Toronto's harsh winter as the most formidable challenge he had to deal with, yet it is one that he eventually overcame. Julie of Turkey cites her lack of English speaking skills as her biggest hurdle. As she recalls, "Actually, I came here by myself, and at that time, I had zero English. I remember I had one sheet of paper at the airport. On it was the message 'I don't have any English. Please help me.' I felt that I was coming from the moon!” For most of the other learners, 
their limited English skills proved to be the biggest challenge, especially for those whose estimations of their English proficiency were higher before they arrived in Canada. For instance, Karim of Palestine states that he thought he knew English when he left his homeland, but once he began interacting with Canadians, he realized that what he had was "broken English". Mona of Iran remembers her frustration with Canadian small talk. To be specific, she mentions the importance of learning which questions most Canadians consider "off the table, such as religion, politics and age." As she puts it, "When I would start a conversation, I would be so self-conscious of my behaviour. And I really didn't have any idea what to say, how to act, so it was challenging."

Although the initial period of adjustment included a flurry of tasks, such as registering for ESL school, securing a health insurance card, finding an apartment, acquiring furniture, registering for child tax benefits and so on, many of the learners recall feelings of excitement at the novelty of everything. Ali, who had been working as an interpreter with the Canadian Forces in Afghanistan, describes his first impression of Toronto as one of bewilderment and euphoria: "So, I landed in Pearson Airport. It was pretty amazing because I came from the third world country to the first world country! The skyscrapers! When I saw the highways and subways and houses, ya, it was pretty different from Afghanistan!"

If one has just left a refugee camp or an extremely volatile political situation, the excitement of arriving in a new country is often only momentary. Constant worries about family and friends left behind or the constant uncertainty about one's own fate can be psychologically debilitating. For example, although Mona entered Canada under government sponsorship, she did not feel secure, as she was still involved in the problem that her family had back home-a political problem. As she reveals, “Because of that, I wasn't completely stable psychologically. I would think all the time about my family. Sometimes when a very bad thing would happen to 
them, I wasn't able to even go to my ESL class. I just wanted to stay at home and stay in touch with my family...."

Like Mona, Karim was plagued by worries about his loved ones, most intensely only five months after his arrival when a major outbreak of violence occurred between Palestine and Israel. In a perpetual state of anxiety and homesickness, he does not recall any degree of "happiness" at all during his first few years in Canada. His anxiety was heightened by the fact that his "hearing was scheduled for just after $9 / 11$ ”. As he remarks, that one pivotal point in history had a farreaching impact on the entire refugee regime by giving politicians and journalists an excuse to conflate "Arab" and "Muslim" - and "Muslim" and "terrorist". After almost two and a half years of having his life on hold, Karim states, "The relief of being accepted was overwhelming."

Similarly, Julie, who made an inland claim, talks about the frustration and anxiety she experienced while waiting for her hearing: "It took almost two and a half years to get the first invitation for the hearing. That day I went with my lawyer and waited for the judge, but the secretary said the judge had an emergency...." Apparently, when the date of her rescheduled hearing approached, Julie's lawyer had an emergency, so again, her hearing was postponed. Understandably, considering this accumulation of postponements, Julie was extremely distraught. As she recalls, "I almost gave up.... Many times, I talked to my family and cried, 'I don't want to be here! I can't find my way here!"' Eventually, however, she got some psychological help. Her hearing came, and she passed. Suddenly, everything changed.

For Ali, any feelings of homesickness were somewhat mitigated by the fact that he was able to come to Canada with his wife and five children and find an apartment in a predominantly Muslim enclave of Toronto where he still resides in relatively close proximity to 40 other Afghans who, like Ali, had their permanent residency applications fast-tracked as a reward for their perilous work as interpreters for the Canadian military. Although the familiarity of Afghan 
grocery stores and a neighbourhood mosque has created a sense of community, and perhaps insulation, for him here, the absence of his extended family continues to be a major source of stress. Comparing life in Toronto to life in Kabul, he remarks that Afghan society is "a collective society, so all people live together-parents, sisters, brothers, and grandchildren — so every family is like ten or twelve people." However, when Ali came to Canada with his family, he was faced with new responsibilities, since his wife spoke no English at that time. As he notes, "To see a doctor here for one appointment, you need three hours, so it's pretty difficult, and each kid has to be registered for daycare. In Afghanistan, my mom was there to help my wife...with the kids."

Newcomers, both refugees and immigrants, face a host of settlement-related issues, yet the current government's increasingly invasive monitoring of ESL learners' attendance indicates a lack of compassion and a lack of appreciation for the enormous stress these learners experience. As teacher Millie states, "I think they come here with such a burden on their backs - to find a job, learn the language, find a place to live, find good schools for their kids." When asked about her role as the enforcer of attendance rules, Millie reveals that in the LINC program, there was "pressure from above to be on the phone every day" to ask where the students were, why they were absent, and when they planned on returning. At first, she complied with instructions from her supervisor to call absent learners. In some cases, the threat of losing their spots in the class, which could, in turn, affect their welfare subsidies, prompted some learners to attend more regularly and stay for the full five hours. However, Millie confesses that she eventually stopped calling. As she explains, “These are adults we're dealing with, not children. Most students would be in school if they really wanted to be there and if they really could be there." In addition, Millie states, "They do have lives...other responsibilities... and some of them have jobs in the evening, so they have to go home...to have a nap or cook for their families....I was never really comfortable getting on that phone." 


\section{3: Breaking the Isolation}

Although some of the learners arrived in Canada with partners - and with children, as in the case of Ali- others arrived alone with only the phone numbers of a few distant acquaintances of relatives. Consequently, for many of the learners whom I interviewed, the ESL classroom constituted the first place in which they were able to build a new network of friends, not superficially for opportunistic purposes, but to feel connected on an emotional level. According to Nadine, it is "fundamental to attend ESL school during the initial stage of settlement for at least a year to break the isolation." Other learners share this opinion, underlining the fact that newcomers cannot be rushed through ESL levels like robots. They need to start off in a non-credit program where there is no pressure to achieve good grades. Definitely, according to all the learners, it takes time to become accustomed to the new society, absorb the language and feel connected. They also claim that being in a supportive ESL class helped stave off feelings of homesickness. As Mei Yi recalls, while she was in her classroom, she was "busy writing, reading, discussing, debating, chit-chatting here and there." She continues: "My imagination was rushing through my mind, visualizing the landscapes, people and traditions my classmates were describing." However, she admits that her homesickness sometimes hit her when she was back in her rented room: "I did think of my family, I did think about the food I was missing, the yearround summer, the beaches...I did become homesick, but I think that's natural." In Mei Yi's case, the ESL classroom was like "a second home", as indicated in the following reflection:

To a certain extent, it was a second home. It provided the social context that I needed at that time. I didn't have friends or family members here. My ESL classroom provided me with that adult interaction I needed...intellectual conversation about what was going on in the city, in the country in terms of politics, sharing information about 
each other's country or family. You know, I think every single human being needs to interact with others in order to function properly. The friendships I formed in ESL class are different from the friendships I formed outside ESL—different in the sense that you relate to that person from the beginning...Those friends are the people you share your first experiences in Canada with. Then the friendships I made later were different kinds of friendships because they revolved around something else. Like the ones I've made with other parents in the schoolyard revolve around my son.

As a testament to the enduring quality of Mei Yi's ESL friendships, she ended up marrying a man whom she met at her ESL school over ten years ago, and two of her closest friends today are former ESL classmates.

Mei Yi's story is not uncommon. For some of the other learners, the friendship ties that formed at their first ESL school have not become frayed with the passage of time. Rather, these ties have grown stronger even though everyone ventured on a separate career path. For example, Nadine's ESL friends still constitute her core friendship circle. As she states, "We don't have the money for going out to eat every weekend, but we do have time to go for a bike ride or to watch a movie at someone's house. Almost every weekend we get together." Nadine also mentions a peculiar observation she has made about Canadians: their ability to "go to movies and do other things by themselves." As she puts it, "If they want to go to the cinema, they can go alone. But in my culture, in Brazil, we do things in groups all the time. It's like... a clan. Here, in the beginning, I was like, 'Where is my group? I need to work fast. I need possibilities.'”

During her first few months in Canada when she was missing her old social life, Nadine admits that she was too dependent on her Canadian husband. She was too insecure to go anywhere by herself because of what she perceived at that time as an inadequate level of English. Now, 
however, she says, "Who cares. I realize in a multicultural place, everybody has an accent, so you just need to be yourself." Nadine would be a quintessential example of the kind of adult ESL student whom Cervatiuc (2009) refers to as a good L2 learner, namely one who demonstrates human agency, creates her own 'imagined community of multilingual and bicultural individuals', and asserts her internal power as she renegotiates her identity in Canada (Cervatiuc, 2009). Certainly, adults in the ESL classroom should not be treated as children, yet the ESL teacher could become sensitive to the possibility that the adult immigrant's self-concept is often in a state of confusion and re-negotiation somewhat similar to that of an immigrant child.

Mona, like Nadine and Mei Yi, feels an enduring connection with her ESL classmates. She states that they formed a kind of "support group", as all of them were either looking for a job or wondering what to do in the future, and they "just followed each other's lives and comforted each other." As she expresses it, "Usually, you try to keep your private life private, but it happened for me many times that I would wake up and think, 'Oh, my God! I don't have any idea what to do with my future!"” According to Mona, it helped to go to ESL class and start having conversations about her frustrations. Several of her classmates became cherished friends. For instance, she refers to a man from Spain who became close to both Mona and her husband. Although this classmate left Canada, she says that she and her husband still maintain contact with him via Facebook, and they "will never forget the quality time they spent with him." Mona also mentions Ana Maria, a Mexican classmate who became her first and best friend in Toronto. Mona refers to Ana Maria as a "life saver" because of the heart-felt support she provided during Toronto's unprecedented ice storm of December 2013:

About a month after I joined the ESL class, there was freezing rain, and no electricity in our part of the city. Being newcomers, we never guessed that this kind of thing could happen in North America... We didn't have any information about the weather when 
we went to a Canadian government workshop for refugees in Turkey. They just showed us a bunch of beautiful pictures from summer. It took us two days to understand that this power failure was something we would deal with for a whole week! Then Ana Maria called me. I didn't call her to tell her that we had no electricity, but she called me and insisted that we come over for Christmas dinner. She meant it when she told us to feel free to come over any time for a shower or a meal. At that moment, I realized that she was one of those people I could always rely on.

While Mona, Mei Yi and Nadine enjoy cross-cultural friendships that developed naturally in ESL class, Julie's ESL friendships were cultivated through a concerted effort to build friendships outside her Turkish social circle. In addition to her Turkish friends, Julie "decided to have friends from different countries" to improve her English. She mentions her close friendships with ESL classmates from Japan, China, Mexico, Iran and France. Although she has not seen her ESL friends very frequently over the past two years, Julie still maintains monthly telephone or Facebook contact with them. In addition, soon after her arrival, she sought friendships with Canadian-born Anglophones by joining a couch surfing network. At the time, her English was quite limited. Nevertheless, like the participants in Cervatiuc's study (2009), Julie "resisted marginalization" by seeking "access into the social networks of [native speakers]" and giving herself credit for her own progress instead of being afraid of opening her mouth to speak English (Cervatiuc, 2009, p. 259).

Of the four male students, it is Josef of Hungary who reports the most enduring emotional attachments to former ESL classmates. Like Mei Yi, Josef remarks that the friendships he developed with ESL classmates seem stronger than the ones he formed later in other social contexts. A decade has passed since he left his ESL school, and his life has become extremely busy with his career and family responsibilities. Even so, he has managed to maintain social ties 
with friends from Syria, Russia, the Democratic Republic of Congo, Iraq, Turkey, and Iran. He fondly recalls the sense of kinship that grew over a period of two and a half years as he moved from one level to the next with the same classmates who were going through similar struggles. As he points out, "Just seeing other people walking in the same shoes can be a very great help. It's relaxing, calming...I found myself feeling more familiar with this country and more comfortable — can I say 'cosier' — in my ESL class. I didn’t feel alone.... I felt like I belonged there." For Josef and his core group of ESL friends, the contact was not confined to the classroom, as they would get together for barbecues or coffee: "We would just sit around a table at a coffee shop after school and discuss our experiences and what we found interesting in Canada - or what we found strange...." If someone had a problem, they would discuss it as a group. According to Josef, "we encouraged each other, so it was a very close, family relationship." It can be argued that the degree of camaraderie that Josef describes resembles the non-threatening, non-judgmental classroom atmosphere that Carl Rogers denotes as empathetic (Rogers, 1980).

One common activity contributing to a family atmosphere is the classroom tradition of the international potluck party in which the learners proudly share their culinary skills and knowledge of their country's traditional dishes. Teacher Angela looks back fondly on the potlucks she had in her class over the years, commenting on how these events "bind students because communal cooking and eating is a common custom in a lot of cultures." Angela's observation is corroborated by the research of Kwik (2008) who writes that the tradition of sharing food-related skills and beliefs "from generation to generation" can be viewed as "a means of asserting cultural identity, particularly for minority culture groups", and "can connect cultural diasporas" (p. 59).

For the learners and teachers alike, this sharing of food was an extremely memorable, community-building experience, rather than a patronizing, superficial display of Canada's 
mosaic. For some of participants in my study, the potluck was a social event occurring only a few times per year to mark the end of a semester, but for others, it constituted a more frequent, informal activity that could be held to celebrate a birthday, Thanksgiving Day, an imminent birth or to welcome back class alumni who had achieved a critical stage in their chosen careers. In one case, this periodic gathering around an array of dishes turned into a networking party, as the teacher made a point of inviting several inspiring former students, role models who had reestablished their careers as dentists, doctors, teachers, engineers, and so on—or who had found entirely new and meaningful directions. Sometimes, a potluck was held to bid a tearful farewell to a classmate who was moving on. For instance, when Mona was asked to recall her most precious ESL classroom moment, her mind went straight to the party that was held for her and another student when they were leaving the class to attend a credit school as a stepping stone towards college. As she states, "It meant a lot to me that my classmates and my teacher actually were caring about my existence there, and they were doing this party for me." Mona's use of the phrase "actually...caring about my existence" suggests Carl Rogers's notion of "prizing” or "unconditional positive regard" of another human being (Rogers, 1995, p. 116). It is also worth

noting that for some of the learners, the potluck was not merely a chance to try different dishes or exchange recipes. Conversations sometimes led from food to deep reflections on homesickness, ailing parents and cultural identity. As Fleming points out, “[t]eachers do not have to turn ESL lessons into group therapy sessions, but we do need to give learners opportunities to engage in class activities with their entire identities" (Fleming, 2003, p.75).

\section{4: The Complexities Involved in Becoming "Canadian"}

The international aspect of their classroom composition is one of the features that contributes to the learners' positive attitudes towards their ESL experiences. All of them were adamant that they preferred being in a "multicultural" class rather than one dominated by people 
from their respective homelands. When attending ESL school, they not only appreciated the novelty of the multicultural atmosphere, but also saw it as a microcosm of Canada itself and thus a welcoming introduction to the country. However, Toronto, renowned as one of the most ethnically diverse cities in the world, is the only Canadian city that these learners have ever lived in. Consequently, when invited to comment on Canada's multiculturalism, they had no other reference points but their own homelands. In most cases, the homeland was described as a monoculture. Karim, for example, reminisces about his wide-eyed wonder when he walked into his first ESL class in Toronto: "Really, ESL school was my first real encounter with Canadian society. In Palestine, contact with other cultures is very limited, especially when you live in a small village." Karim adds, "In the past, whenever tourists came, we would run to speak with them. It was just one culture.... so when you come here, you realize no culture is better than others." He remarks that he will always remember his first ESL classmates here and how much they all respected each other. His list includes individuals from China, Japan, Albania, Turkey, Syria, Greece, Korea, Iraq, Russia and Romania, among others. According to Karim, this initial multicultural experience in the ESL classroom is important, as "it helps you wherever you go later. You learn to respect everyone. You listen to everyone. Multiculturalism is something you really appreciate."

The perception of the "Canadian" identity as a dominant white Anglo identity still emerges from under the surface in some of the learners' responses when asked to comment on "being Canadian". Their responses raise the nebulous issue of what constitutes the "Canadian identity". For instance, Mei Yi admits that she was already "culturally confused" during her childhood and adolescence in Panama, since she was considered "Chinese" to the Panamanians, but "Panamanian" to the Chinese, and her parents insisted that she and her sibling were "entirely Chinese" even though China was totally unknown to them. Now, after more than a decade in 
Canada, Mei Yi says that she still feels "culturally Chinese Panamanian" and "emotionally Canadian". As she explains, "I think I do feel Canadian to a certain point, but not $100 \%$...This is where we laid the foundation for our life. Canada is where my kids were born....I have worked and matured a lot here, and I'm staying put....But even though I have Canadian citizenship now and feel loyalty to Canada, I still love my homeland.” Mei Yi’s response reinforces the notion that an immigrant's lingering emotional attachment to a beloved homeland somehow precludes a full commitment to a "Canadian" identity despite the fact that the official discourse of inclusiveness and diversity is supposedly the essence of being "Canadian". The idealized concept of multiculturalism seems to be deeply embraced by all the learners, and it contributes to the sense of belonging that they are seeking. At least, as Cervatiuc argues, learners may have increased levels of self-confidence when they focus "on their internal power", that is, their perception of “equality and worthiness as multilingual and multicultural individuals..." (Cervatiuc, 2009, p. 268). However, as several scholars have recognized, when the liberal multicultural mosaic is placed in the larger context of Canada's history of colonialism, it begins to look like a thin façade (Bartolomé, 2010; Gibb, 2008; Kubota, 2010; Guo, 2013).

The comments of other learners also suggest a positive yet ambiguous concept of multiculturalism. When I asked Nadine for her definition of the "Canadian" identity, she emitted a nervous laugh before stating, "I don't know! In my country, we know what it is to be Brazilian, but here you have a variety of cultures. Or maybe that's it. To be Canadian is to become a multicultural person. I don't know if it's possible....But maybe it's good not to have just one national dish." Echoing this sentiment, Mona admits that before coming to Canada, she had the impression that a Canadian was a person who was white and of British ancestry, but now she realizes that "even people who were born here are all immigrants, so anybody can be a Canadian." According to Mona, "the multiculturalism here is one of the reasons that all kinds of immigrants 
can fit into the society very well." As she explains, "When you walk into the street and you see people with all colours and speaking all different languages, it gives you a sense of security...that there are many like you." At the same time, Mona concedes that it might be different in a small town where the local people have had only limited exposure to other cultures, "so they don't even know how to react." She admits that being conspicuous, either in a positive or a negative way, would make her feel uncomfortable. According to Mona, "If you are treated special all the timeit doesn't matter if it is positive discrimination or negative discrimination - then you cannot feel this is your home."

The utopian image of racial equality and a multicultural national identity is also extremely appealing to Ali, and it has afforded him a sense of freedom, the freedom to express his Afghan identity. He states that Canada's multiculturalism is evidenced by the fact that he is "allowed to wear [his] national clothes in public" without anyone questioning him. He especially appreciates the principal of his former adult high school in Toronto for dedicating a classroom for the afternoon prayer and instructing all the teachers to excuse the Muslim students when it was time for them to go and pray. As Ali elucidates, “Here people don't care whether you're Muslim or Christian or Buddhist... What is important is the life of the human being." He contrasts this respect for religious freedom to the situation in Kabul where he says a Christian would have to "walk with four security guards and an armoured car."

While Ali expresses the belief that his teachers and the school administrators genuinely embraced the concept of cultural diversity, a few of his ESL memories point to the contrary, as they suggest that Canadian culture was presented to him at ESL school through one white lens. For example, he reveals that he did not meet expectations in his initial English placement test at Megacity Adult School because he did not have the "correct" response to the question, "Why do Canadians like long holidays?" Ali claims that he "really didn't know the answer because [he] 
had never been taught about the history and culture of Canada" when he was studying English in Afghanistan. He later learned that the "correct" answer was the fact that "Canada has nine months of winter". As he explains, "Later I found out Canadians like long holidays to go outside for barbecues and outdoor activities. But I didn't know that before, so I wrote something else that was totally different." Consequently, Ali was placed in a lower level English class. This experience taught him that "the most important thing is to learn about Canadian history and the Canadian social life." He adds, "Afghanistan has a history of war and invasion....so before we come here, we don't know about Canadian outdoor activities or how to do barbecues." Ali's story reaffirms the Freirean notion of the banking of knowledge that is used to "minimize or annul the students" creative power" (Freire, 2000, p. 73). It also speaks volumes about the ambiguity of an "imagined community". Indeed, the learners whom I interviewed seem to have embraced the promise of multiculturalism: an imagined egalitarian community. However, the ideal of the cultural mosaic is inconsistent with the unilingual, monocultural discourse entrenched not only in the government's language and immigration policies, but also in ESL curriculum documents. Citing a study by Thompson and Derwig (2004), Yan Guo (2013) points out that the bulk of the content they examined in numerous LINC program textbooks reflects a white, Anglo-Saxon, middleclass, Christian perspective rather than a more nuanced, multi-faceted one that would legitimize the cultural realities of non-British or racialized Canadians.

Referring to the theme of becoming Canadian, some of the learners express intense opposition to the Anglicization of names, while others are resigned to it. Mtobe refers to such a practice as "cheating". He emphatically declares, "My name means everything. I have my dad's name, so I can't change it. My kids have my name. It's like a continuation of the family. I can't change my name. I can't!” While Mtobe and many of the other learners see their names as intrinsic to their identities, some of them mention other newcomers in Toronto who feel they have 
no choice but to adopt an English name in order to get that coveted call to come for a job interview. As Nadine comments, “Personally, I don't like this idea...But many immigrants feel daily embarrassment when somebody cannot pronounce their names. When I attended Brownstone College, I met some mature Chinese students who changed their names to feel comfortable in social environments. So, it is sad, but this is the reality." The learners' remarks on the Anglicization of "foreign-sounding” names bring to mind Yan Guo's research on this subject. Guo (2013) questions the message that some ELT teachers and employment counsellors are sending to newcomers by encouraging them to adopt a "Canadian" nickname. According to Guo, some newcomers accept the Anglicization of their names as a necessity in the Canadian labour market and as a signal that they are prepared to integrate by erasing markers of their ethnic identities. Fortunately, however, none of the learners I spoke with hold this view.

\section{5: How Language Excludes}

The pressure to conform to a normative, white culture becomes apparent when we examine the growing demand in the Canadian labour market for a "non-foreign" variety of English that most closely resembles what the employer deems an acceptable or superior standard of English (Guo, 2013). The recent introduction of English language proficiency tests as a requirement for citizenship further reinforces the supremacy of "standard" varieties of English and the exclusion of a substantial portion of the world's population (Shohamy, 2007). In the interviews I conducted with former ESL learners, accent discrimination emerges as another common theme, but feelings towards it differ. According to Josef, this form of discrimination, albeit hurtful, is a "natural" reaction to difference. As he remarks, "Yes, sometimes when I was looking for a job, I felt like I was treated differently because of my accent, but I thought it was natural that they would want to hire someone with fluent English instead of someone like me. It was a little painful, but I kept telling myself that in a short time, I would improve my English, and I would no longer experience 
this type of discrimination." In fact, he adds that the accent discrimination he faced was the impetus steering him towards a full-time ESL class. While Josef seems to accept native-like fluency as a legitimate demand, Mtobe, as a proud native speaker of Canada's other official language, sees no need for ESL accent reduction lessons. Since his French-accented English is tied to his sense of self, it is not something he would ever want to erase even if he could. As he states, "If you're a newcomer, you're a newcomer. You have to accept that. Why would you want to change who you are?"

Another perspective is offered by Angela. When asked if she ever felt compelled to teach her students about the dominant, white, Anglo culture as representative of Canadian culture, she replied, "It's a balancing act. Realistically, you have to do that to some extent because they're living in that dominant culture, and they have to know how it works. It surrounds them, so they have to be able to express themselves in that culture." However, Angela qualifies her statement, pointing out that even though the learners have to be aware of the culture that surrounds them in order to survive and move ahead, the ESL teacher can present that dominant culture in a way that still "validates or emphasizes individual learners' own cultures and what they bring to this country in terms of their own experience." Nora Jung (2013) argues that the expectation that learners "conform to the dominant culture....indicates that they are considered "malleable, just like children, rather than fully formed adults with firm beliefs" (p. 569). According to Jung, adult ESL learners are often infantilized in various settings.

This infantilization is corroborated by some of the women learners I interviewed. In their telephone interactions with Canadians, they sometimes experience subtle and overt forms of accent discrimination and a patronizing tone that makes them feel belittled. To illustrate, Julie reveals that when she phoned a customer service department recently, the woman at the other end of the line, detecting Julie's Turkish accent, “began to laugh”. In Julie's re-enactment of that 
conversation, the laugh was a half-suppressed one, a snicker. She feels that some Canadians deliberately try to diminish her dignity because of her Turkish accent. As she puts it, "This kind of stuff happens a lot. Come on! I asked you a question. This is your job to serve me! But they don't want to bother having a conversation with you... and they know you can't find the correct words to talk back more. They know you don't have the same level of their English. It's all racism!"” Julie adds, “I don't know what Canadians are thinking about immigrants. Maybe they think we're destroying their country, but they don't know us. I want to say to them, 'Just tell me how many languages you know! I will tell you how many I know!’” Despite such encounters and her less than perfect English, Julie is resilient, optimistic and, in her words, "passionate about education".

Mona also mentions hurtful and humiliating experiences that occurred when she was volunteering at a community tax clinic. Her task was to book appointments for clients. Although she was speaking English, her intonation, rhythm and pronunciation marked her as a foreigner, as the Other. Hence, in the estimation of the clients, her voice did not carry authority. As Mona recalls, "Many of the clients sounded like they were pitying me and talking to me like I was a child...you know, how you talk to a very small child. They asked me to just refer them to 'an English speaker'. They were so strict about it and refused to talk to me." According to Mona, most of the community centre's clients were elderly or working class people who couldn't afford an accountant, so she was doing them a favour as a volunteer. However, she states, "they thought they were doing me a favour by speaking to me extra slowly, like they were tolerating my accent. Or sometimes they would use words like 'darling' or 'honey'. I would understand right away that this was not normal." The condescending reactions of these callers have left their mark on Mona's psyche, as she emphatically declares, “As an ESL student, the very first concern for all of us is not to be judged on how we speak, not to be judged on our accent!" 
The incidents related by Julie and Mona support the findings of Tomic (2013) and Creese (2010) who found that accent devaluation is often condoned because of the embeddedness of a racialized linguistic hierarchy. According to Mtobe, Canada's other official language ranks below English. He concedes that the fact that he is a Francophone affords him some linguistic capital in this officially bilingual country, and it has compensated to some extent for his lack of English fluency. However, he objects to the fact that French does not have equal status. As Mtobe points out, "Ontario is supposed to be a bilingual province, but I've noticed when you go on the subway, all the announcements are in English, not French. Being a Francophone, I feel that perhaps we are considered less than people who speak English..." He adds, "Why do they give power to English-speaking people, but not the French-speaking people? It's not fair!”

Interestingly, while Mtobe speaks vociferously about the linguistic power imbalance in Canada, he does not mention the issue of Canada's racial power imbalance. He insists that throughout his 15 years here he has never encountered any form of racial discrimination, although he does admit that he has "heard bad stories about it from African friends who immigrated to Europe". For Mtobe, the main issue is the lower status of French. Also, he acknowledges that all other minority languages should be respected, but without government funding for heritage language programs. As he explains, "I think only about English and French.” Conversely, Julie supports the proposal of linguistic minority rights, stating, "Even though my English is okay because I can understand what people want to get from me, I sometimes get stuck. If I had a choice to get the question in my language, then I would understand better. It's not just about French and English now. If somebody is allowed to live here, they should have services in their language."

Not surprisingly, all but two of the learners vehemently oppose the federal government's attachment of language proficiency to citizenship. When I informed Nadine that applicants up to 
the age of 64 are required to take a government-approved language test, she uttered, "That's absurd! Many of them...have a history of life and work in Canada and have been out of school for a long time. A written test cannot express their level of contribution to this country!" Karim recounts the story of an Italian man he met here who arrived as an adult and never attended English classes: "This guy told me that he'd been working in construction with Italians since his arrival, so he didn't need English. How can you tell him he can't become a Canadian citizen? I mean he paid taxes. He worked very hard, harder than many Canadians who speak fluent English. So after 35 years here, he has to write an IELTS test? It's not fair!”

The normalization of "Standard English" as the ideal to which immigrants should aspire is ubiquitous. Consciously or unconsciously, "educators, as agents of world English, are to some degree facilitating McDonaldization....” (Phillipson, 1998, p. 111). It is being perpetuated by the entire ESL bureaucracy in Canada, since "[e]ducational institutions are primary sites of 'standard language ideology" (Creese, 2010, p. 301). Ali offers further support for this notion with his memory of one ESL teacher who had a stringent "English only" rule in her classroom and refused to allow the Afghan students to sit near each other. According to Ali, she said, "You must never talk in your own language if you want to go to college or university." As Ali recalls, there were almost eleven Afghans in the class, and the teacher jumped to the assumption that they would speak "in [their] own language" if they were sitting too close to each other, so she demanded that they sit apart. Consequently, some of the Afghans in the class protested, but to no avail. This silencing of dissent in the classroom, instead of engaging in meaningful dialoguing about it, was a behaviour that Ali had already grown to accept as a classroom norm before he arrived in Canada. 


\section{6: A Teacher's Influence}

Reflections on individual teachers comprise a substantial portion of the learners'

narratives. They discuss not only the personality traits of their former ESL teachers, but also the kind of classroom atmosphere they found conducive to learning, specifically, an atmosphere characterized by empathy, respect and intimacy. Some of the learners also mention the role of power. During my interview with Ali, I asked him whether he thought it was important for students to like a teacher as a human being in order to learn more effectively. His response struck me with its raw candidness and conviction: "I see the teacher has more power than the prime minister. Yes, the teacher has more power than the prime minister!” As he elucidates, One of my nephews was in university in civil engineering during 1998, the Mujahideen time. His father was a Communist, and his professor was a fundamentalist Islamist.... So my nephew said that the professor already knew his father had a position in the Communist party. Then one day, my nephew asked him, "Why are you always saying bad things about Communists?" Then the professor introduced my nephew to the class as the "bad" student, and he was faced with withdrawal from the university forever. I still remember that story, so if my teachers say anything wrong, I would never say anything. I know that teachers in all the world have full authority. They can increase your mark or decrease your mark. I told myself that even in Canada, I would never say, "You're wrong." Whatever the teacher teaches me, I will follow, so I never face a problem.

The experience of Ali's nephew brings to mind both Paulo Freire and Carl Rogers, for it dramatically illustrates the kind of education system that they would have found abhorrent. Writing about a student's "constant fear of failure", Rogers asserts that this fear rises "as we go up the educational ladder, because the student has more to lose" (Rogers, 1995, p. 296). Ali's 
story about his nephew also exemplifies how a student's dissenting voice can be silenced in an instant by an authoritarian figure and how a message of fear can become rooted in the psyche. Although the above incident occurred in Afghanistan, the abuse of power is happening in insidious ways in classrooms throughout so-called 'democratic' countries (Giroux, 2012).

One point on which all the learners concur is the crucial role played by the classroom teacher and the influence that a teacher's personality can have on the creation of either a climate of boredom and discomfort or one of open communication and human empathy—in other words, a climate conducive to solidarity building and personal growth. It is interesting to note that when asked to list three adjectives that would describe their favourite ESL teachers, many of the learners state qualities that one would associate with teachers who have a humanistic orientation. Among the many adjectives mentioned, the following words are the most salient: "patient", friendly", "approachable”, "non-judgmental", "understanding” and "welcoming”. Two of the learners also point to the importance of "a sense of humour" in creating a comfortable atmosphere. Karim underscores the need for a teacher with "endurance", as he claims that "there are students who learn very slowly, others who learn very fast...and some teachers cannot cope with that difference and don't have the patience to keep working with the very slow learners."

Another highly appreciated quality emerging in many narratives is "empathy". Although not all of the learners used the word "empathy", their descriptions of situations and relationships definitely reflect an empathetic quality. Remembering her favourite teacher, Mei Yi points out, "She had the patience to really listen and comprehend. She really related to all her students as individuals. More than a teacher, she was a friend to her students and would...make them feel that they belonged." Echoing Mei Yi’s comments, Julie mentions Edna, her favourite teacher, as one who "was more human" because she could identify with the students and she understood "the immigrant feeling”. Reminiscing about Edna, Julie remarks, 
She was from South America and grew up here...but she could understand our sadness, that something was missing in our hearts. And she never ever judged us for anything....I know another teacher can judge a student's accent or something else... If you don't like your class or you think your teacher doesn't care, you don't want to go to her class, but when you feel your teacher really cares about you and knows who you are, it gives you a totally different feeling.

This appreciation for empathetic warmth is further emphasized by Nadine who repeatedly uses the word "personable" to describe her favourite teacher. In her view, a personable teacher is one who gives the class "that space for talking...time to socialize, to talk about themselves and their cultures." Her description of that space continues:

Oh, my God! I was feeling immediately the family environment. We were focusing on grammar, but [the teacher] also gave the time to build the social side, a place where students feel comfortable sharing..... I think classes reflect pretty much the teacher's passions, interests and views. After a couple of months studying with an ESL teacher, you can tell many things about him or her just based on his or her observations, methods and favourite topics. And the students can feel if that teacher is really one who likes people....You just know it. It's about body language. It's about gestures. It's about the way that person looks at you. When you talk to someone who doesn't have this soft skill, there's just this wall. You cannot reach that person. It's difficult to approach this person if she's just talking to you, teaching you without any feelings. Nadine's comments reinforce Rogers's assertion that "[e]mpathy gives that needed confirmation that one does exist as a separate, valued person with an identity" (Rogers, 1995, p.155). In the context of the multicultural classroom, this degree of empathy is especially meaningful, as it crosses and often blurs cultural boundaries. 
The responses of all the learners reaffirm the value of an ESL teacher who demonstrates not only empathy, but also respect for each learner's lived experience and a genuinely nonauthoritarian personality—qualities at the heart of humanistic pedagogy. For some of the learners, who were unaccustomed to teachers who treat students as adults, the diminished social distance was refreshing. As Julie remarks, "In level three, my teacher was so friendly. We could go outside and drink coffee with her. I remember this really good feeling I had....It was amazing because in my country, teachers were higher people." According to Julie, "You couldn't reach their level, so if I could communicate with a teacher like a friend, it made me feel more confident and powerful. Whenever I left the coffee shop after our chat, I felt proud of myself.” Josef fondly recalls Belinda, an ESL teacher with whom he spent over a year. In that time, she became "like a good friend, not just a teacher." He states that Belinda made them "feel comfortable in this country, and not afraid." Mtobe also reminisces about a teacher who was more like a friend or a sister. At Christmas, she would invite some of the students who were alone here to have Christmas dinner at her home. Her sincere thoughtfulness is something that Mtobe says he "will always remember with deep gratitude." To varying degrees, all the learners can remember at least one teacher with whom they enjoyed a trusting relationship of mutual admiration, respect and openness that extended beyond their time in the classroom.

Throughout my conversations with the learners and the teachers, it is evident that the teacher sets the tone and the degree of intimacy among the learners. According to Mona, "it's really important to be able to have a conversation freely, so the teacher shouldn't be judgmental at all." Mei Yi claims that when the teacher is friendly and informal, "students will feel more at ease when asking questions" and this comfort level "will foster better learning." As a teacher with a "casual teaching style", Millie admits that it was inevitable that she would develop a close relationship with her students. When asked what she did to create a comfortable learning 
environment, she mentions that she was simply very straightforward and open in her class, sometimes just "clowning around", talking about herself a bit, and her family, being herself. There was never much social distance between Millie and her learners. As she reveals, "I never sat behind my desk, never gave them the message 'I'm the teacher, and you're the students'. It's not like you're teaching children. This atmosphere was good for them and good for me. They learned, and I learned." According to her description of the intimate atmosphere in her class, she was already practising elements of the humanistic approach by being her authentic, flawed self. In the words of Carl Rogers, "It is so obvious when someone is not hiding behind a façade but is speaking from deep within himself. When this happens, I leap to meet it. I want to encounter this real person" (Rogers,1995, p.16). Although Millie is now retired, she still keeps in fairly close contact with certain former students via the Internet and occasionally goes out for coffee or potluck picnic lunches with them.

In Angela's case, however, her social contact with learners outside the classroom dissipated after she retired. Nevertheless, she acknowledges the need to treat learners as equals and not become an authority figure in the classroom. As she puts it, "You have to start from the premise that these learners are adults and some of them have been through pretty traumatic life experiences, and they bring that to the classroom all the time. They have lives." Angela recalls emotional connections with particular students whom she admired and to whom she became an emotional support. She remembers occasions when she would be included in learners' family celebrations at their homes. However, she views this degree of attachment as a natural, albeit temporary, part of the learner's process of trying to integrate into Canadian society. As she explains, "You, as the teacher, are a part of that process. If you can help move that process along, then [the students] really have less and less of a need for your contribution once they feel more confident." 
All the learners whom I interviewed are forthright about the qualities of the ideal ESL teacher, and they are equally vocal about what they do not appreciate in an ESL teacher. According to Nadine, the focus on social relationships was missing when she moved up to the next level. As she reports, "It was zero social relationships in my next class, so we never really...you know what I mean....Some teachers just don't want that kind of relationship with the student as a person. Maybe they're just comfortable doing their job.” Despite the higher level teacher's obvious intelligence and knowledge, Nadine feels that this teacher was not the kind of person who "really cares deeply about you, what you think, really cares about what you did on the weekend..." Like Nadine, Karim comments on the ineffectiveness of teachers who view their teaching jobs simply as a source of income: "There are teachers who are probably very informative and highly educated, but they cannot reach their students. They don't know how to transfer their knowledge...." According to Mei Yi, "enthusiasm" is one of the essential ingredients in a teacher, as “boredom doesn't help with the learning process", a fact she discovered when she had a very boring ESL computer teacher. For Ali, "feeling respected" is of utmost importance. Again, he singles out the principal of Megacity Adult School who made all the Afghan students feel welcomed and validated through his obvious efforts to learn all their names and get to know them as individuals.

It should also be acknowledged that all the learners recognize those teachers who stepped far outside the boundaries of their job descriptions in their efforts to help students empower themselves and cope with the stress of settlement. Teachers Angela and Millie maintain that sometimes they had no choice but to wear several hats, including job coach counsellor, social worker, housing advisor, parenting instructor and social advocate. Often they made themselves available simply as non-judgmental listeners. As compassionate human beings, they could not help getting involved in the lives of their students. Angela recalls that there were "many, many 
instances when [she] couldn't just walk out of the classroom" and go home when a student approached her after class and opened up about some personal issue. She also refers to the time when a group of politicized learners in her school turned to her for assistance when they were organizing a campaign to keep the library of their school open during a time of severe fiscal restraint. Similarly, Millie recalls students confiding in her, "crying on [her] shoulder" for a host of reasons, including marital strife, immigration issues, isolation, and financial problems that forced them to stop attending class. She also mentions that she had a few students who were living in a shelter because of domestic abuse, but notes, "It's all mixed up with the isolation of being here and not having the family support network they had back home... As a teacher you wear many hats - and maybe a bit of teaching thrown in.” According to Millie, “There simply aren't enough hours in the day to do all that you want to do for your students." Both Angela and Millie comment on the time-consuming nature of their work as a direct consequence of the heightened level of bureaucracy.

\section{7: Preserving Teacher Autonomy}

Frustration emerges as a common feeling in the interviews with the two retired teachers in reference to the policing of students and the escalating volume of administrative tasks related to accountability. Angela does not hesitate to link the decline in staff morale at her former school to the cutbacks and the increasingly top-down bureaucratization of ESL. As she states, "The tighter the funds, the tighter the administration. The reality is that if the government wants to know where every cent is going, the job of the ESL administration is to provide the documentation, the figures." According to Millie, this increased accountability necessitates overwhelming paper work that teachers are required to complete on their own time. For her, the major source of pressure was "the numbers game", the fear of class closure because of low attendance... always being under the gun for numbers." She maintains that this situation "sometimes took away from [her] teaching". 
Due to precarious enrollment, the threat of class closure was always looming. Millie partly attributes the declining enrollment to changes in assessment procedures. She recalls that a decade ago, new students could walk in off the street, get assessed at the school and get assigned to the appropriate class. Now, however, any prospective learners have to book an appointment for a more formal assessment at one of a handful of centralized assessment centres across Toronto, and often they get sent to another ESL location. In Millie's estimation, the "old system" saved a lot of time for the students, and allowed for flexibility and a personalized approach, as there was daily interaction between the assessor and the teachers. Consequently, students could move up or down a level at any point in the term upon the recommendation of their teacher.

Not only are ESL teachers today expected to monitor learner attendance, but they are also required to implement the curriculum guidelines of the Canadian Language Benchmarks (CIC, 2012). However, not all teachers do it wholeheartedly. Fleming (2010) found that ESL instructors who are implementing the CLB curriculum, and who are grounded in the communicative methodology, "still wanted autonomy over classroom materials and activities" (p. 30). Now safely retired, Millie reveals that she exercised non-compliance. When asked to comment on how she incorporated the CLB materials into her lessons, she confesses that the CLB materials were not of much use to her, so she stopped using these documents altogether. In Millie's view, “it's a hindrance to standardize. I mean everyone learns in a different way....You can take parts of it, but I usually did my own thing and gave my students what they wanted. They're the ones who know what they want and need..." For instance, she points out that not everyone is comfortable doing small group or pair work. Also, certain real-life tasks, such as writing a letter of complaint to a landlord, were designated as sample tasks for a particular competency at a particular level in the CLB curriculum, but "in real life", there could be a need for such letters at any level. Millie adds, 
"You can't force anything. I would always ask my students what they wanted. Idioms? Writing? Phrasal verbs? Sometimes they'd generate a list of discussion topics on the board before lunch and I'd ask them to pick their top three to discuss after lunch." Millie recalls that at first, "it seemed a daring thing to be asked what they were interested in", but she instructed them to pretend that she wasn't there. She adds that free-flowing discussions could last all afternoon and even spill over to the next day. Conversation topics included euthanasia, gender inequality, capital punishment, abortion. No topics were barred.

Although the learners are divided on the value of standardized CLB assessment criteria across Canada, they are unanimous in their support of teacher autonomy in terms of curriculum design. Most of them believe that teachers should be entrusted with complete latitude in terms of what and how they teach. In Mtobe's words, "The teachers are the ones in daily contact with the students. The federal government doesn't know the individual students." Mona concurs, pointing out that "there's no way the government could guess all of the needs and make one curriculum for the whole country." She perceptively points out that ESL classes are diverse, composed of individuals of all ages, personalities, and cultural backgrounds and from different education systems, so a one-size-fits-all curriculum is unrealistic. In short, as Mei Yi expresses it, "The government should loosen its grip... and leave the curriculum up to individual teachers."

\section{8: Transformative Learning Experiences}

A significant theme emerging from the interviews with former students and teachers is the potential for transformative learning experiences in an ESL classroom. Some of the learners' ESL experiences could be viewed as examples of transformative learning, which is generally defined as "the process of using a prior interpretation to construe a new or revised interpretation of the meaning of one's experience in order to guide future action" (Mezirow, 1996, p.162). 
Many of the learners report that they enjoyed the classroom opportunities for selfexpression and critical thinking through discussions and writing. They often confronted highly controversial and personal topics that led them to critical self-reflection and new perspectives on the past, the present and the future. While most of Ali's ESL teachers at the credit high school steered away from politics and religion for fear of classroom conflicts that "would upset the students”, Mei Yi “discussed everything” in her low-advanced, non-credit ESL class. As an illustration, she recalls an intellectually stimulating and heated debate on a religious issue in a classroom of Christians, Muslims, Buddhists—and one staunch, argumentative atheist. Mona maintains that her ability to think critically and express her opinions in English was developed in the intimacy of her ESL classroom, as she felt free to write on topics that she ordinarily would not have discussed with anyone. Specifically, she mentions that she did a presentation on dictatorship, a topic that she would never have had the chance to talk about in any school in Iran. She also recalls writing about a personal incident of sexual abuse in her homeland: "I kind of buried those feelings in me, and I never talked about them, mostly because I didn't want to be seen as a victim, but the very first time I started to think about that incident again and let another person know about those feelings was when I wrote about it in my [non-credit] ESL class, and I shared it with my teacher."

Another illustration of a transformative learning experience is offered by Ali who found himself reflecting deeply on contentious, emotional issues pertaining to the society he had recently left. This pivotal experience occurred when his teacher had asked him to select a novel and keep a weekly journal about his impressions. Ali chose Khaled Hosseini's A Thousand Splendid Suns, a novel set in Afghanistan and written by a fellow Afghan. Ali describes its impact: "When I was reading for half an hour, I was crying. I could picture the scenes he was 
writing about and all the social, political and emotional aspects. I was reading for half an hour and then I cried for half an hour. I really appreciate Khaled Hosseini."

Certainly, being exposed for the first time to classmates who have survived horrific experiences could have a profound, life-changing impact on learners with a heightened sense of compassion. Nadine relates how she would sometimes arrive home feeling drained and humbled by the stories of devastation and resilience she had heard from her classmates: "I had never met any refugees before coming to Canada, but in my ESL class, I was meeting people who had come from war." One particular anecdote is etched in Nadine's memory. As she reports, "I remember one fellow who had been in a sinking boat full of people...[He] saved a mother, and that mother had four kids. He was just able to save the mother. He had nightmares every night. It was so powerful....You really start to think about your life."

For other learners, simply being introduced to the format of small group discussions - in which the teacher is not the only one with knowledge to impart—was in itself transformative. According to Karim, "This method teaches you team work, how to really listen and analyze. I was used to people in my country always speaking, speaking, speaking over each other. But now I realize that listening is a very important thing." His opinion is echoed by Ali who claims that the critical thinking skills he developed in one of his ESL classes helped him to question society: "If there is no critical thinking, you need to always follow other people." 


\section{CHAPTER 7: PEDAGOGICAL IMPLICATIONS}

As I indicated in the introduction, teachers with an anti-colonial mindset and a sincere belief in humanistic principles could disrupt the growing neoliberal trends in Canada's centralized ESL system that keeps many newcomers marginalized. In other words, the onus is on individual teachers to dare to go far beyond the safe, depoliticized version of multiculturalism confined to food, music, dance and costumes. Individually and collectively, teachers could begin to bring deeper meaning and power to the word "multiculturalism" by following two overriding principles: respect for the dignity of learners and their lived experiences and a commitment to their empowerment. Ultimately, such a commitment necessitates that teachers become self-reflective by confronting their own prejudices. It also requires that they critically examine their roles in the settlement process. Since ESL teachers are often the first "Canadians" from whom many newcomers learn about this country, it is essential that teachers begin to unpack governmentapproved curriculum and citizenship materials for traces of colonialism and assimilative messages. The works mentioned in my literature review and the ten interviews that I conducted reinforce the need to educate teachers and learners about the hidden agenda and to find ways to make the ideology of multiculturalism a vehicle for empowerment rather than disempowerment.

I argue that a starting point towards empowerment can be found in the humanistic pedagogical approaches of Freire and Rogers. It would be naïve to assume that humanistic pedagogy constitutes a panacea for social inequities or the guaranteed key to deep second language acquisition. Also, in a large, multicultural ESL classroom, it would be impractical and impossible to cater to the psychological needs and methodological preferences of each student. Speaking from my own experience, I have found that students are unpredictable and cannot be expected to respond alike. Various affective and sociological factors come into play. For instance, role-playing activities might heighten self-esteem in some learners, while other learners might 
view such a technique as far too strange and build up thicker walls of silence. One learner might be able to write a cogently argued essay about the world poverty crisis while never venturing to open his mouth about it in class. ESL teachers must accept all the individual differences in learning styles and respect silences and "the right to pass" (Moskowitz, 1978, p. 30). Even so, regardless of their varying learning styles, personalities and political outlooks, all learners could benefit from the essence of humanistic learning - that is, the principle of empathy and its restorative, solidarity-building possibilities.

A genuine commitment to empowerment might also require that teachers become activists and take the bold step of ignoring the imposed curriculum. Instead, they could introduce a nuanced, unsanitized version of Canadian history and society, and blur the boundary between teacher and student. Doing so without losing one's learners involves the building of trust, which is a gradual process. As Millie cautions, ESL learners are human beings who have uprooted themselves, sometimes from traumatic situations, so “you can't get in their faces. First, you have to let them feel comfortable with you... Then slowly, perhaps they will open up a little bit." Angela and several of the learners echo this sentiment. When asked how teachers could help make inhibited, new students feel comfortable enough to open their mouths, Josef emphasizes that teachers “shouldn't push new students to speak English all the time. If they force the issue, the student can have anxiety and not speak at all after a while." Another learner also mentions that shy new learners could be intimidated by being expected to "jump in", especially when they arrive in the middle of a problem-posing discussion on a controversial sociopolitical issue or any activity involving self-disclosure.

In incorporating the concepts of Carl Rogers and Paulo Freire in today’s ESL classroom, we must remember that these two inspirational thinkers developed their thoughts on education and departed from this world long before social media became ubiquitous. Thus, they did not 
consider the pervasiveness of modern technology in education. They could not have predicted how PowerPoint, Facebook and Twitter might interfere with the kind of intimacy required in a humanistic classroom. However, technology does not necessarily have to pose a threat. It could be used to disseminate thought-provoking, counter-hegemonic messages. At the same time, perhaps certain slower-paced, humanistic exercises could be woven into the daily schedule expressly to provide a much needed respite from the speed of modern technology. In fact, the suggestion of taking an occasional break from technology emerged during several of my interviews. For example, Karim admits that since he is "not a person with the most computeroriented mentality", he prefers "the old way of going to school and socializing in a classroom". He laments the fact that "we've become a society of online everything, computers and robots." As he puts it, "Life should not be like that. It should be about humans, respect, connecting faceto-face." Similarly, Julie maintains that we must start worrying about how modern technology is "making [us] separated from human relationships." She claims that "the Internet is not real", for in "a real class", you can see "how the voice goes up and down... and you can see the person's eyes and mouth. You can mimic. Everything is combined."

Another point to consider is the therapeutic value of creative writing and visual art as vehicles for self-expression. Josef mentions that although he experienced serious anxiety when he had to give presentations in class, he would derive pleasure and satisfaction from opportunities to share his skills as a photographer and painter. As he states, "Ya, we had a lot of chances to show our talent back then. We even had some art exhibitions at my ESL school. And we did a lot of creative writing. Some of us contributed to a yearly book." According to Josef, seeing their stories and poems in print provided "a boost, a feeling of being important and talented....People need to show their creativity." Unfortunately, due to government cutbacks and the growing focus on job training, there is little money left in ESL school budgets for purely artistic pursuits. 
Furthermore, ESL teachers must acknowledge the fact that they will never be able to reach all of their students through a humanistic methodology, since some learners will want to adhere to certain learning techniques that have worked for them in the past. Also, the rationale for any activity needs to be thoroughly explained, since motivation must be accompanied by investment in a particular learning environment (Norton, 2012). "The notion of investment... conceives of the language learner as having a complex social history..." and "an investment in the target language is also an investment in the learner's own identity..." (Norton, 2012, pp.5051). Norton's message is explicitly reinforced by Julie when asked to comment on motivation: 'Even if you kill yourself to show students something very important about English, if they don't agree with you or they don't care, they can't learn anything."

The inescapable reality is that many newcomers are motivated by the desire to "get ahead" in mainstream Canadian society, and the message they receive from various sources, including employment counsellors and the media, is that the key to getting ahead is looking and sounding as if you were born here. As Angela suggests, we cannot ignore the reality of the dominant, Anglocentric culture. It is the culture that surrounds us, especially outside of large urban areas. Since knowledge is power, ESL teachers with a counter-hegemonic philosophy would be doing their learners a disservice by withholding lessons on the dominant culture's norms. Certainly, teachers need to equip their learners with the sociolinguistic tools to survive in the competitive workplace, but the imparting of knowledge about mainstream Canadian society, including workplace culture, can be done sensitively and critically from an anti-colonial perspective that does not present the dominant culture as superior and something to which newcomers must aspire. Also, acquiring knowledge of their new society does not mean that they have to avoid speaking their mother tongues in public or shed markers of their countries of origin or religion. In other words, they do not have to succumb to assimilation. In a humanistic-oriented ESL 
classroom, the teacher could be instrumental in helping adult newcomers negotiate healthy cultural identities simply by giving them space to express themselves honestly, develop critical thinking and feel genuinely respected as individuals.

ESL teachers need to look inward and explore their own feelings and reactions, their own preconceived ideas about various cultures, races and religions. They can begin by asking themselves the following questions:

- What kind of assumption or expectation am I communicating through my selection of books or films - through my facial expressions, tone of voice, or sanitized presentations of Canadian history?

- In organizing "multicultural festivals", am I essentializing my students and their homelands as cardboard representations out of a tourist brochure by inviting them to wear their "national costumes" for photo opportunities?

- Am I trying to "rescue" learners instead of providing them with tools to make their own choices and develop agency?

- Am I trying hard enough to listen to them with they are speaking, or am I encouraging them to develop a CBC-radio accent of "Canadian" English?

- Am I prizing the uniqueness of all my students as individuals, or am I pre-judging them according to media reports about their countries?

- Am I infantilizing my learners by speaking too slowly and over articulating?

- Am I giving my learners space to express their thoughts and feelings in a variety of ways and introducing them to knowledge that will help them assert their rights and question "authority"?

- Am I measuring their degree of integration according to how closely they approximate a white, Anglo-American normative standard? 
It is incumbent upon ESL teachers to become self-reflective, flexible and open to change. No humanistic "techniques" can be meaningful when teachers hold stereotypical views of their students and support the government's assimilative agenda. The first step in the consciousnessraising of ESL teachers is an examination of their own complicity in perpetuating deeply ingrained, hegemonic power structures. As George Sefa Dei (2002) reminds us, "the sources and uses of data are not apolitical", because "our constructions of knowledge" have "profound social and political contexts and consequences" (p. 9). In other words, there is no such thing as a neutral curriculum. I would add that there is no such thing as a neutral teacher. According to Fleming (2003), teachers have a profound influence on the learners' dynamic process of identity construction, as he asserts:

We can stymie this process by continuing to transmit the mythos of a monolithic and Anglocentric Canadian culture or we can seriously engage our learners and ourselves in the construction of the kind of Canadian culture we want to build. Links between the construction of personal and nation-state identities should be explicitly made in the classroom. This task is of vital importance not only to ourselves as teachers and learners, but also to the nation in which we live. (Fleming, 2003, p. 77) 


\section{CHAPTER 8: CONCLUSION}

In the minds of some cynics, terms such as "self-actualization" and "empowerment" might seem naively idealistic, but when we look around at the current state of the world, the meanings embodied by these words are not vague clichés from the 1970s. In light of the economic imperative in our education system, in concert with Canada's increasingly restrictive immigration and language policies, the fundamental humanistic messages of Paulo Freire and Carl Rogers are still relevant and worth considering. It can be argued that a Freirean-Rogerian pedagogical philosophy is useful for those ESL teachers who are interested in providing a genuinely inclusive atmosphere and a psychological respite from our growing dependence on computer technology. Moreover, such an approach could help counter the dehumanizing impact of the growing standardization of ESL programs by facilitating meaningful communication in the classroom and helping newcomers negotiate their cultural identities as they look critically at the world.

ESL teachers might not be able to convince all of their learners of the valid rationale behind solidarity building, socio-political debates, open-ended humanistic exercises, and depictions of Canadian culture that veer from the British Canadian culture presented in our citizenship preparation material. Nonetheless, it is worthwhile to keep trying. It is also important to remain cognizant of the fact that learners are adults who come to the classroom with a wealth of unique lived experiences. By wholeheartedly embracing a person-centered, humanistic approach, teachers would have to relinquish their own authority to a large extent (Rogers, 1995). The prospect of narrowing the teacher-student social distance, thus altering the traditional classroom power structure, could be daunting to insecure teachers who cherish their authority in the classroom. In fact, it could be perceived as a "terrifying" threat, and a "political threat" (Rogers, 1995, p. 304). Although some teachers would never consider doing what Bartolomé (2010) suggests by "daring to infuse" a counter-hegemonic ideology into their lessons, at least 
they could begin to humanize the learning environment by prizing the autonomy, intelligence and lived experiences of their learners and by helping them develop critical thinking and creativity instead of passively conforming to a government-designed curriculum. As Paulo Freire states, "Leaders who do not act dialogically, but insist on imposing their decisions, do not organize the people - they manipulate them. They do not liberate, nor are they liberated: they oppress" (Freire, 2000, p.178). This aspect of teacher self-reflection leads to Mary Pratt's notion of the contact zone: "social spaces where disparate cultures meet, clash and grapple with each other, often in contexts of highly asymmetrical relations of power..." (Pratt, 1991, p. 530). As Pratt suggests, crossing the boundaries between cultures and negotiating cross-cultural understanding can be transformative. An empathetic classroom atmosphere could provide both ESL learners and teachers with avenues for self-expression, creativity and agency. Hopefully, it might lead some teachers to become activists, as they find individual ways to challenge the xenophobic agenda in the government's language policies. Perhaps it might also lead to a consideration of an ideology of multilingualism that goes far beyond heritage language programs for children.

According to Giroux \& Giroux (2006), critical pedagogy necessitates critiquing curriculum materials, incorporating "radical classroom practices", and "linking learning to social change, education to democracy, and knowledge to acts of intervention in public life" (p. 28). Hence, ESL teachers who want to uphold democracy need to raise their own consciousness levels by analyzing ESL curriculum documents next to Canada's language, immigration and citizenship policies. In doing so, they could begin to explore alternate ways of knowing and belonging. As Castles (2000) states, the reality of transnationalism and multiple citizenships brings to the forefront the notion of cultural and political "belonging" and underscores the impracticality of basing citizenship policies on cultural homogeneity or language fluency. 
On the frontline, in the intimacy of their classrooms, teachers are in a unique advocacy position. By empowering their learners, they can empower themselves and resist the perpetuation of the racialized linguistic hierarchy that exacerbates the problem of social exclusion. Attempts to incorporate a humanistic pedagogy and return ESL to the grassroots, community level could contribute to the humanization of an otherwise dehumanizing system and give immigrants and refugees a chance to feel a genuine sense of belonging. Furthermore, it could be liberating and enlightening for ESL teachers to disrupt the state's agenda and stand back to create more space for self-expression. The following excerpt from my interview with Nadine of Brazil poignantly encapsulates the value of contesting the growing ESL bureaucracy and truly listening to our learners:

I'm not saying that the teacher should be...should act like a mother or father. I'm saying that maybe the teacher should...try to know the students as human beings, their stories, the stories they need to tell. I don't know...to spend time with them sometimes in a different environment... because they're people, right? It's not just about learning the language. It's about everything. In this country, you need to develop your hard skills, but also your soft skills, and sometimes you just need a chance to talk about your problems and express yourself....People look at you and think you must be happy all the time. You know, Carnaval, beaches, always summer. But we have cold areas in my country too. And they expect you to know all about soccer, but I'm not a soccer person. And you wonder, "How can I express myself? How can I show my real personality?" If you're not allowed to show who you are, it's difficult. When you come to Canada, you're confused. You need to sometimes repeat to yourself, "Who am I? How am I changing?" 


\section{REFERENCES}

Andres, V. D. (2002). The influence of affective variables on EFL/ESL learning and teaching. The journal of the imagination in language learning and teaching, 7, 1-5.

Arnold, J. and Brown, H.D. (1999). A map of the terrain. In Arnold J. (Ed.). Affect in Language Learning. Cambridge University Press.

Bartolomé, L. I. (2010). Daring to infuse ideology into language-teacher education. Critical Multiculturalism: Theory and Praxis, 47.

Bourdieu, P. (1991). Language and symbolic power. Harvard University Press.

Brown, H.D. (Brown, H. D. (2000). Principles of language teaching and learning. White Plains, NY: Longman.

Castles, S. (2000). Citizenship and the other in the age of migration. In Ethnicity and Globalization: From Migrant Worker to Transnational Citizen. London: Sage Publications. Chapter 12, 187-202.

CELPIP website. Retrieved June 30, 2015 from https://www.celpiptest.ca/

Cervatiuc, A. (2009). Identity, good language learning, and adult immigrants in Canada. Journal of Language, Identity and Education, 8, 254-271.

Citizenship and Immigration Canada (CIC). (2004). Backgrounder-Citizenship and Immigration Canada enhanced language training initiative. Retrieved April 1, 2015 from http://www.cic.gc.ca/english/department/media/backgrounders/2004/2004-05-07.asp

Citizenship and Immigration Canada. (2009). Discover Canada: The Rights and Responsibilities of Citizenship. Ottawa: Minister of Public Works and Government Services.

Citizenship and Immigration Canada (CIC). (2013). Backgrounder-Language Instruction for Newcomers to Canada (LINC) program. Retrieved June 3, 2015 from http://www.cic.gc.ca/english/department/media/backgrounders/2013/2013-10-18.asp 
Citizenship and Immigration Canada (CIC). (2015a) Strengthening Canadian Citizenship Act: A before and after view of the key changes to the Citizenship Act. Retrieved July 2, 2015 from http://news.gc.ca/web/article-en.do?nid=985219

Citizenship and Immigration Canada (CIC). (2015b). Language Testing—Skilled Immigrants. Retrieved May 30, 2015 from http://www.cic.gc.ca/english/immigrate/skilled /languagetesting.asp

Citizenship and Immigration Canada (CIC). (2015c). Express Entry-Comprehensive Ranking System (CRS) Criteria. Retrieved June 24, 2015 from http://www.cic.gc.ca/english/express- entry/grid-crs.asp

Citizenship and Immigration Canada (CIC). (2015d) Express Entry Rounds of Invitations. Retrieved July 19, 2015 from http://www.cic.gc.ca/english/express-entry/rounds.asp Creese, G. (2010). Erasing English language competency: African migrants in Vancouver, Canada. Journal of International, 11(3), 295-313.

Cummins, J. (2000). Language, power, and pedagogy: Bilingual children in the crossfire (Vol. 23). Multilingual Matters.

Cummins, J. (2001). Negotiating Identities: Education for Empowerment in a Diverse Society, $2^{\text {nd }}$ Edn. Los Angeles, CA: California Association for Bilingual Education.

Cummins, J. (2007). Rethinking monolingual instructional strategies in multilingual classrooms. Canadian Journal of Applied Linguistics/Revue canadienne de linguistique appliqué, $10(2), 221-240$.

Dei, G. J. S. (2002). Spiritual knowing and transformative learning. The Research Network for New Approaches to Lifelong Learning, 4-16.

Ellsworth, E. (1989). Why doesn't this feel empowering? Working through the repressive myths of Critical pedagogy. Harvard Educational Review, 59(3), 297-324. 
Fleming, D. (1998). Autonomy and agency in curriculum decision-making: A study of instructors in a Canadian adult settlement ESL program. TESL Canada Journal, 16(1).

Fleming. D. (2003). Building personal and nation-state identities: Research and practice, TESL Canada Journal, 20(2), 65-79.

Fleming, D. (2010). Becoming Citizens: Racialized conceptions of ESL learners and the Canadian Language Benchmarks. Canadian Journal of Education, 33(3), 588-616.

Fleming, D., \& Morgan, B. (2011). Discordant anthems: ESL and critical citizenship education. Peer Review Collection, 2011, 30.

Fleming, D. (2015). Encounters with Second Language Education Bureaucrats: Misunderstandings and Misgivings. Citizenship Education Research Journal, 4(1), 80-88.

Freire, P. (2000). Pedagogy of the Oppressed: New Revised, 30th Anniversary Edition. Continuum.

Gibb, T.L. (2010). Sites for discussion, citizenship education and pathbuilding: Challenging the fear of controversy in the adult EAL classroom. Journal of Contemporary Issues in Education, 4(2).

Gibb, T. L. (2008). Bridging Canadian adult second language education and essential skills policies. Approach with caution. Adult Education Quarterly, 58(4), 318-334.

Giroux, H. A., \& Giroux, S. S. (2006). Challenging neoliberalism's new world order: The promise of critical pedagogy. Cultural Studies $\leftrightarrow$ Critical Methodologies, 6(1), 21-32.

Giroux, H. A. (2011). On critical pedagogy. Bloomsbury Publishing USA.

Giroux, H.A. (2012). Education and the crisis of public values. Peter Lang Publishing, Inc.

Guo, Y. (2013). Language policies and programs for adult immigrants in Canada: A critical analysis. Canadian Ethnic Studies, 45(1), 23-41. 
hooks, b. (1994). Teaching to transgress: education as the practice of freedom. New York:

Routledge.

IELTS Canada website. Retrieved July 2, 2015 from https://www.ieltscanada.ca/

Jung, N. (2013). Putting adult back into adult ESL education. International Journal of Arts \& Sciences. 6(3), 557-579.

Kaushal, A., \& Dauvergne, C. (2011). The growing culture of exclusion: Trends in Canadian refugee exclusions. International Journal of Refugee Law, 23(1), 54-92.

Kobayashi, A. \& Peake, L. (2000). Racism out of place: Thoughts on whiteness and an antiracist geography in the New Millennium. Annals of the Association of American Geographers, 90 (2), 392-403.

Krashen, S.D. (1981). Second Language Acquisition and Second Language Learning. Oxford University Press.

Kubota, R. (2010). Critical Multicultural Education and Second/Foreign Language Teaching. In May, S. and Sleeter, C.E. (Eds.). Critical Multiculturalism Theory and Praxis. Routledge, 99-111.

Kwik, J. (2008). Traditional food knowledge: A case study of an immigrant Canadian “foodscape". Environments Journal. 36(1), 59-71.

Maslow, A. (1987). H. (1970) Motivation and personality.

May, S., \& Sleeter, C. E. (Eds.). (2010). Introduction. In May \& Sleeter (Eds.). Critical multiculturalism: Theory and praxis. Routledge.

McLaren. P. (1999). A pedagogy of possibility: Reflecting upon Paulo Freire's politics of education. Educational Researcher, 28(2), 49-54.

Mezirow, J. (1997). Transformative learning: Theory to practice. New directions for adult and continuing education, 1997(74), 5-12. 
Moskowitz, G. (1978). Caring and Sharing in the Foreign Language Class: A sourcebook on Humanistic Techniques. Newbury house.

Moskowitz, G. (1999). Enhancing personal development: humanistic activities at work. In In Arnold, J. (Ed.). Affect in Language Learning, 177-193.

Neuman, W. L. (2011). Social research methods: Quantitative and qualitative approaches (7th Edition). Boston: Allyn and Bacon.

Norton, B. (2013). Identity and language learning: Extending the conversation. Multilingual matters.

Norton, B. (2001). Non-participation, imagined communities and the language classroom. Learner contributions to language learning: New directions in research, 6(2), 159-171.

Norton, B. (1997). Language, identity, and the ownership of English. TESOL quarterly, 31(3), 409-429.

O’Hara, M. (2003). Cultivating consciousness: Carol R. Rogers's person-centered group process as transformative andragogy. Journal of Transformative Education, 1(1), 64-79.

O'Hara, M. (1989). Person-Centered approach as conscientizacao: The works of Carl Rogers and Paulo Freire. Journal of Humanistic Psychology, 29(1), 11-35.

Oxford, R. L. (1999). Anxiety and the language learner: New insights. In Arnold, J. (Ed.). Affect in language learning, 58-67.

Phillipson, R. (1998). Globalizing English: are linguistic human rights an alternative to linguistic Imperialism? Language Sciences, 20(2), 101-112.

Pratt, M.L. (1991). Arts of the contact zone. Profession, 33-40.

Rinvolucri, M. (1999). The humanistic exercise. In Arnold, J. (Ed.). Affect in language learning, 194-210. 
Rogers, C. R., Lyon, H. C., \& Tausch, R. (2013). On becoming a teacher: Person-centered teaching, psychology, philosophy, and dialogues with Carl R. Rogers and Harold Lyon. Routledge.

Rogers, C. (1995). A way of being. Houghton Mifflin Harcourt.

Rogers, C. (1977). On personal power: inner strength and its revolutionary impact. New York: Delacorte.

Shohamy, E. (2007). Language tests as language policy tools. Assessment in Education, 14(1), 117-130.

Skutnabb-Kangas, T. (1998). Human rights and language wrongs-a future for diversity? Language Sciences, 20(1), 5-27.

Stevick, E. (1999). Affect in learning and memory: From alchemy to chemistry 1. In Arnold, J. (Ed.). Affect in Language Learning. Cambridge University Press, 43-57.

Tomic, P. (2013). The colour of language: Accent devaluation and resistance in Latin American immigrant lives in Canada. Canadian Ethnic Studies. 45(102), 1-11. 